\title{
Surface circulation and upwelling patterns around Sri Lanka
}

\author{
A. de Vos ${ }^{1,2,3}$, C. B. Pattiaratchi ${ }^{1}$, and E. M. S. Wijeratne ${ }^{1}$ \\ ${ }^{1}$ School of Civil, Environmental and Mining Engineering \& The UWA Oceans Institute, University of Western Australia, \\ 35 Stirling Highway, Crawley, Western Australia 6009, Australia \\ ${ }^{2}$ The Centre for Ocean Health, The University of California Santa Cruz, CA 95060, USA \\ ${ }^{3}$ The Sri Lankan Blue Whale Project, 131 W.A.D. Ramanayake Mawatha, Colombo 2, Sri Lanka
}

Correspondence to: A. de Vos (asha.devos@lincoln.oxon.org)

Received: 15 August 2013 - Published in Biogeosciences Discuss.: 11 September 2013

Revised: 26 August 2014 - Accepted: 5 September 2014 - Published: 30 October 2014

\begin{abstract}
Sri Lanka occupies a unique location within the equatorial belt in the northern Indian Ocean, with the Arabian Sea on its western side and the Bay of Bengal on its eastern side, and experiences bi-annually reversing monsoon winds. Aggregations of blue whale (Balaenoptera musculus) have been observed along the southern coast of Sri Lanka during the northeast (NE) monsoon, when satellite imagery indicates lower productivity in the surface waters. This study explored elements of the dynamics of the surface circulation and coastal upwelling in the waters around Sri Lanka using satellite imagery and numerical simulations using the Regional Ocean Modelling System (ROMS). The model was run for 3 years to examine the seasonal and shorter-term ( $\sim 10$ days) variability. The results reproduced correctly the reversing current system, between the Equator and Sri Lanka, in response to the changing wind field: the eastward flowing Southwest Monsoon Current (SMC) during the southwest (SW) monsoon transporting $11.5 \mathrm{~Sv}$ (mean over 2010 2012) and the westward flowing Northeast Monsoon Current (NMC) transporting 9.6 Sv during the NE monsoon, respectively. A recirculation feature located to the east of Sri Lanka during the SW monsoon, the Sri Lanka Dome, is shown to result from the interaction between the SMC and the island of Sri Lanka. Along the eastern and western coasts, during both monsoon periods, flow is southward converging along the southern coast. During the SW monsoon, the island deflects the eastward flowing SMC southward, whilst along the eastern coast, the southward flow results from the Sri Lanka Dome recirculation. The major upwelling region, during both monsoon periods, is located along the southern coast, resulting from southward flow converging along the southern coast and subsequent divergence associated with the offshore
\end{abstract}

transport of water. Higher surface chlorophyll concentrations were observed during the SW monsoon. The location of the flow convergence and hence the upwelling centre was dependent on the relative strengths of wind-driven flow along the eastern and western coasts: during the SW (NE) monsoon, the flow along the western (eastern) coast was stronger, migrating the upwelling centre to the east (west).

\section{Introduction}

Sri Lanka is situated within the equatorial belt in the northern Indian Ocean, with the Arabian Sea on its western side and the Bay of Bengal on its eastern side (Fig. 1). In an oceanographic sense, the location of Sri Lanka is unique, with its offshore waters transporting water with different properties through reversing ocean currents driven by monsoon winds. The northern Indian Ocean is characterised by bi-annually reversing monsoon winds resulting from the seasonal differential heating and cooling of the continental land mass and the ocean. The Southwest (SW) monsoon generally operates between June and October, and the Northeast (NE) monsoon operates from December through April (Tomczak and Godfrey, 2003). The transition periods are termed the first intermonsoon (May) and the second inter-monsoon (November). During the SW monsoon, the Southwest Monsoon Current (SMC) flows from west to east, transporting higher salinity water from the Arabian Sea, whilst during the NE monsoon, the currents reverse in direction, with the Northeast Monsoon Current (NMC) transporting lower salinity water originating from the Bay of Bengal from east to west (Schott and McCreary, 2001). During the SW monsoon, increased 


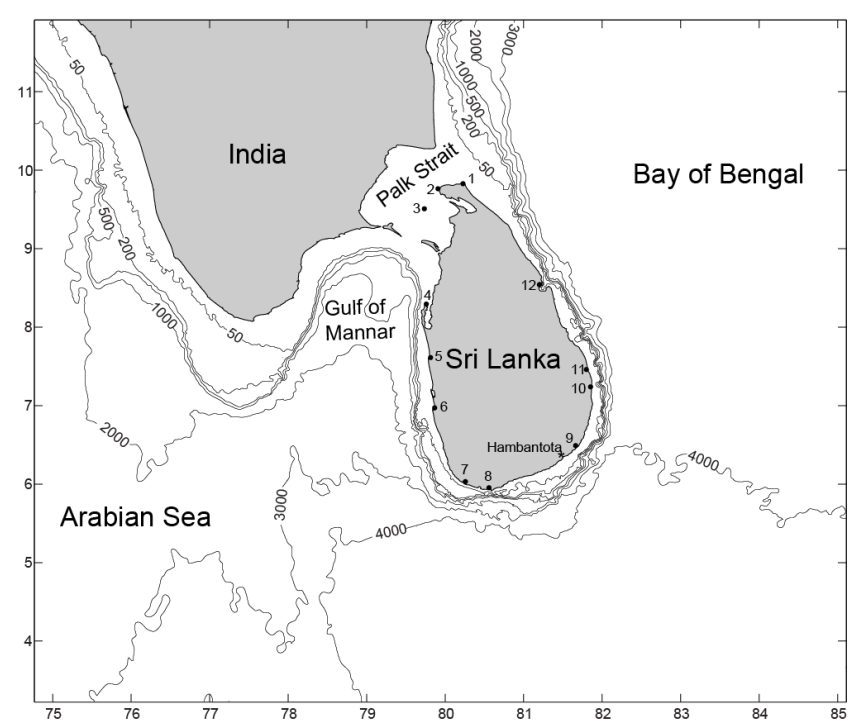

Figure 1. Study area showing the bathymetry and model domain. Numbers represent tide stations used for model validation. 1. Point Pedro 2. Kayts 3. Delft Island 4. Kalpitiya 5. Chilaw 6. Colombo 7. Galle 8. Dondra 9. Kirinda 10. Oluwil 11. Batticaloa 12. Trincomalee. Wind speed and direction data were from the Hambantota meteorological station on the southeastern coast.

chlorophyll concentrations $\left(>5 \mathrm{mg} \mathrm{m}^{-3}\right.$ ) have been recorded around Sri Lanka, particularly along the southern coast (Vinayachandran et al., 2004), which appears to be a major upwelling region. These elevated chlorophyll concentrations persist for more than four months and have been attributed to coastal upwelling, advection by the SMC and open ocean Ekman pumping (Vinayachandran et al., 2004). During the SW monsoon, where the winds blow parallel to the coast, winds are upwelling favourable in terms of Ekman dynamics. Chlorophyll concentrations during the NE monsoon appear to be low, but there is evidence of high productivity through the documented feeding aggregations of blue whales (Balaenoptera musculus) along the southern coast of Sri Lanka (de Vos et al., 2014). Field observations have shown that $\sim 6-$ 10 whales are sighted per day along the southern coast of Sri Lanka (data from 2009 to 2011). The region also has a well-developed whale watching tourism industry. At present, there is a lack of information regarding the environmental features that influence the distribution of blue whales in the waters of Sri Lanka. Therefore, the aim of this paper was to examine the oceanographic features that may influence the distribution of the blue whales off the southern coast of Sri Lanka. Due to a paucity of field data, previous research has focused on the analysis of satellite imagery and coarseresolution models designed to simulate basin-scale features. In this paper we use satellite imagery and a high spatial resolution numerical model (ROMS) with realistic and idealised forcing to investigate the flow patterns and upwelling mechanisms, particularly off the southern coast of Sri Lanka.
The continental shelf around Sri Lanka is narrower, shallower and steeper than is average for the world (Wijeyananda, 1997). Its mean width is $20 \mathrm{~km}$, and it is narrowest on the southwestern coast, where it is less than $10 \mathrm{~km}$ (Shepard, 1963; Swan, 1983; Wijeyananda, 1997). The continental slope around Sri Lanka is a concave feature that extends from $100 \mathrm{~m}$ to $4000 \mathrm{~m}$ in depth. The continental slope on the southern and eastern coasts has an inclination of $45^{\circ}$, which is one of the steepest recorded globally (Sahini, 1982). The abyssal plain around the island is $3000-4000 \mathrm{~m}$ deep (Swan, 1983).

The seasonal difference in sea surface salinity ( $>2 \mathrm{ppt})$ around Sri Lanka is highly significant compared to other regions (Levitus et al., 1994). Salinity in the Bay of Bengal is generally lower $(<33 \mathrm{ppt})$, whilst salinities in the Arabian Sea are higher, with maxima up to $36.5 \mathrm{ppt}$ due to high evaporation and negligible freshwater input. The Bay of Bengal receives $\sim 1500 \mathrm{~km}^{3} \mathrm{yr}^{-1}$ of freshwater through freshwater run-off, whilst the total freshwater input into the Arabian Sea is $\sim 190 \mathrm{~km}^{3} \mathrm{yr}^{-1}$ (Jensen, 2001). Including evaporation and rain, the Arabian Sea experiences a negative freshwater supply of about $1 \mathrm{myr}^{-1}$, whereas there is a positive freshwater supply of about $0.4 \mathrm{myr}^{-1}$ to the Bay of Bengal (Jensen, 2001).

The mean sea level pressure (SLP) in the northern Indian region is at a maximum from December to January and at a minimum from June to July, with a mean seasonal range of $5-10 \mathrm{hPa}$ (Wijeratne, 2003). There is significant seasonal variation in sea level in the northeastern Indian Ocean, with a range in the inner Bay of Bengal of $\sim 0.80-0.90 \mathrm{~m}$, decreasing to the south (Wijeratne, 2003); hence, the mean sea level is $0.05 \mathrm{~m}$ lower in January compared to July, due to the inverse barometric effect. The seasonal sea level variability around Sri Lankan waters is around $0.2-0.3 \mathrm{~m}$, with maxima during June through the action of the SW monsoon (Wijeratne et al., 2008). The tides around the island are mixed semidiurnal with a maximum spring tidal range of $\sim 0.70 \mathrm{~m}$.

The surface circulation of the northern Indian Ocean may be described after Schott and McCreary (2001). A schematic of the circulation in the northern Indian Ocean in the vicinity of Sri Lanka during the SW monsoon is shown in Fig. 2b. Along India and Sri Lanka, the eastern boundary current, or West Indian Coastal Current (WICC) in the Arabian Sea, flows southwards along the western Indian coastline and joins the eastward flowing Southwest Monsoon Current (SMC). Shankar et al. (2002) also postulated a westerly flow from the southern-central Arabian Sea entraining water into the SMC. The presence of the anti-clockwise Lakshadweep eddy off the southwestern coast of India modifies the current flow in this region. The SMC flows along the southern coast of Sri Lanka from west to east (Schott et al., 1994), transporting $\sim 8 \mathrm{~Sv}\left(1 \mathrm{~Sv}=10^{6} \mathrm{~m}^{3} \mathrm{~s}^{-1}\right)$ between the Equator and Sri Lanka. After passing the coast of Sri Lanka, the currents form an anti-clockwise eddy defined as the Sri Lanka Dome (SLD) centered around $83^{\circ} \mathrm{E}$ and $7^{\circ} \mathrm{N}$ 

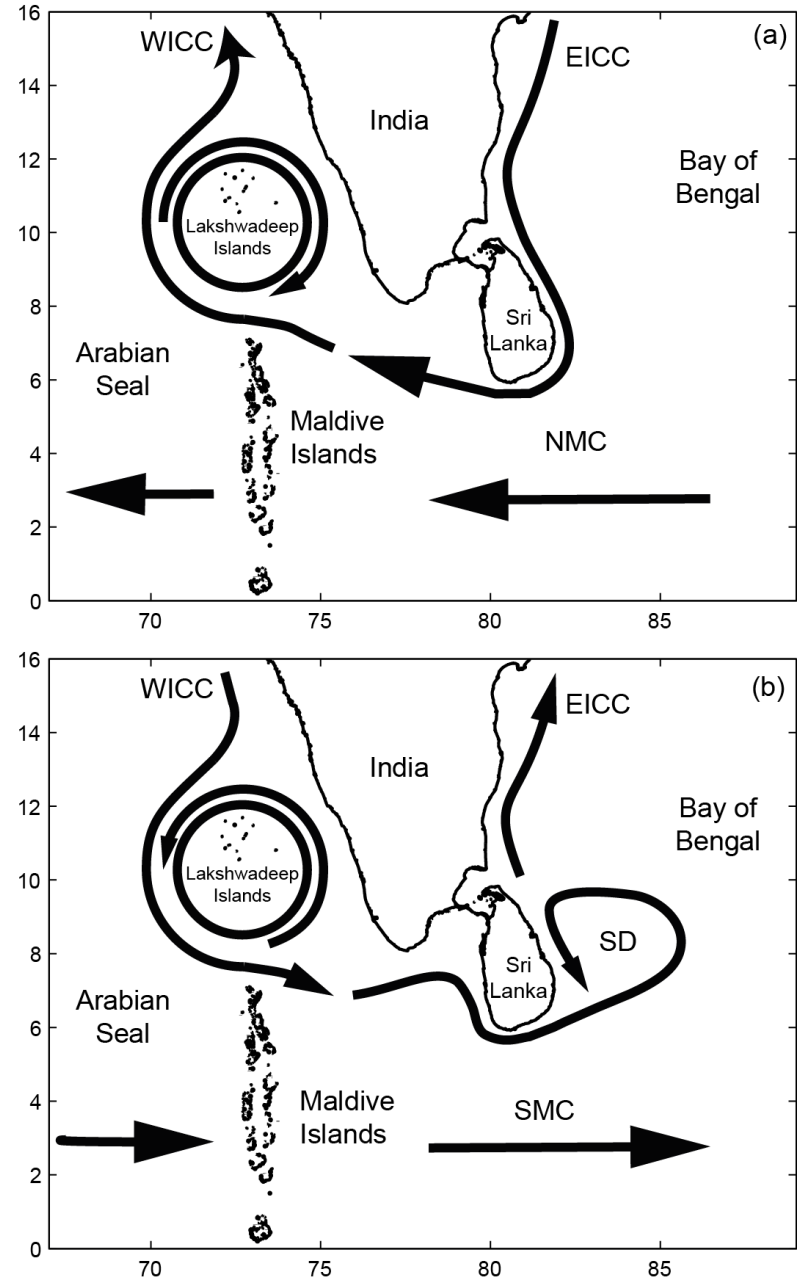

Figure 2. Circulation patterns around Sri Lanka and southern India for the (a) Northeast monsoon and the (b) Southwest monsoon. WICC - West Indian Coastal Current; EICC - East Indian Coastal Current; SMC - South Monsoon Current; NMC - North Monsoon Current; SD - Sri Lanka Dome.

(Vinayachandran and Yamagata, 1998). The western arm of this eddy drives a southward current along the eastern coast of Sri Lanka, whilst the remainder flows northward along the eastern Indian coast as the East Indian Coastal Current (EICC).

During the NE monsoon, the currents reverse direction (Fig. 2a). Along the eastern Indian coast, the EICC flows southward past Sri Lanka and joins the Northeast Monsoon Current (NMC) flowing from east to west, transporting about $12 \mathrm{~Sv}$ (Schott et al., 1994). The currents then flow around the clockwise Lakshadweep eddy and northward along the western Indian coastline as the West Indian Coastal Current (WICC).

One of main features to note from this description from the perspective of Sri Lanka is the reversal of currents along the western and southern coasts and the north-to-south flow along the eastern coast. This circulation pattern was confirmed by Shankar et al. (2002). However, Varkey et al. (1996) and Shankar and Shetye (1997) both provide a different interpretation, and suggest that currents along the eastern coast of Sri Lanka flow south to north irrespective of season. However, using altimeter data, Durand et al. (2009) have shown a seasonal reversal of the currents along the eastern coast of Sri Lanka.

Sri Lanka is a relatively large island (length $440 \mathrm{~km}$; width $225 \mathrm{~km}$ ), extending offshore into the Indian Ocean, similar to a headland. This allows the island to interact with the seasonally reversing monsoon. Many studies have reported the influence of flow interaction with islands and headlands leading to enhanced primary production - termed the island mass effect (IME) by Doty and Oguri (1956). These studies have included different spatial scales using laboratory and field experiments to understand circulation and enhanced productivity. They include those in the vicinity of oceanic islands: Johnston Atoll (Barkley, 1972), Aldabra and Cosmoledo atolls (Heywood et al., 1990), Barbados (Bowman et al., 1996; Cowen and Castro, 1994), the Canary Islands (Barton et al., 2000), the Kerguelen Islands (Bucciarelli et al., 2001), Madeira (Caldeira et al., 2002), the Galapagos Islands (Palacios, 2002), Hawaii (Hafner and Xie, 2003), Santa Catalina (Dong and McWilliams, 2007); and, in continental shelf and coastal regions, Wolanski et al. (1984), Pattiaratchi et al. (1987) and Alaee et al. (2007). Many scaling arguments have been proposed to define the circulation patterns in the lee of islands based on the Reynolds number which appears to reproduce the observed circulation in the lee of the island/headland (Tomczak, 1988; Wolanski et al., 1984). The Reynolds number for the deep ocean is defined as (Tomczak, 1988): $R_{\mathrm{e}}=U L / K_{\mathrm{h}}$, where $U$ is the velocity scale, $L$ a length scale, and $K_{\mathrm{h}}$ the horizontal eddy viscosity. The nature of the wake downstream of an island can be predicted using the Reynolds number. For low values of $R_{\mathrm{e}}(\sim 1)$, there is no perceptible wake with the flow attached to the island (the "attached" flow condition; Alaee et al., 2007). For $R_{\mathrm{e}}$ between 1 and 40, the wake consists of two attached eddies. At higher values of $R_{\mathrm{e}}$, the wake becomes increasingly unstable, and counter-rotating eddies form a vortex street (Tomczak, 1988). Flow past a curved coastline can also lead to secondary circulation: here, as a result of the curvature-induced centrifugal acceleration, the surface waters move offshore and are replaced by water from the sub-surface (Alaee et al., 2004).

Alaee et al. (2004) examined the secondary circulation induced by both the flow curvature and the Coriolis effect, for quasi-steady oceanic flows. Using scaling of the transverse momentum equation, Alaee et al. (2004) developed a flow regime diagram to predict the strength of the secondary flow $U_{\mathrm{n}}$ for different flow regimes and also to provide information on the relative importance of the flow curvature and the Coriolis effect in the generation of the secondary flow. 
The upwelling off the southern coast of Sri Lanka usually appears and intensifies during the summer months, when the SW monsoon prevails, and is said to be due to a combination of wind-driven Ekman transport, advection by the SMC and open ocean Ekman pumping (McCreary Jr. et al., 2009; Vinayachandran et al., 1999, 2004). Monthly satellite image composites of chlorophyll analysed by Yapa (2009) show high-productivity waters with mean chlorophyll concentrations of more than $5 \mathrm{mg} \mathrm{m}^{-3}$ along the southern and western regions during the months of June to August that are accompanied by a $2^{\circ}$ to $3^{\circ} \mathrm{C}$ decrease in sea surface temperature (SST) corresponding to regions where high chlorophyll a concentrations are detected. To illustrate this relationship, MODIS images indicate the strong relationship between higher chlorophyll and cooler SSTs (Fig. 3). Data collected during the Dr. Fridtjof Nansen cruises between 1978 and 1989 provide evidence that the SW monsoon bloom results from upwelling that begins closer to the coast, and progresses further offshore as it develops over subsequent months (Saetersdal et al., 1999). Michisaki et al. (1996) confirmed high primary productivity when they recorded maximum nitrate concentrations of approximately $10 \mu \mathrm{M}$ in midJune, accompanied by maximum chlorophyll concentrations of $0.9 \mathrm{mg} \mathrm{m}^{-3}$ off the western coast of Sri Lanka.

The aim of this paper is to define the seasonal changes in circulation and upwelling patterns around Sri Lanka using a high-resolution numerical model (ROMS) including realistic forcing complemented by satellite imagery. The motivation for the paper is the observation of blue whale (Balaenoptera musculus) feeding aggregations off the southern coast of Sri Lanka during the NE monsoon period (de Vos et al., 2014), despite satellite imagery indicating lower productivity in the surface waters. This paper is organised as follows: in Sect. 2, we describe the numerical model configuration and validation, Sect. 3 presents the results from analysis of the wind fields, satellite imagery and numerical model output including idealised simulations to examine upwelling generation mechanisms, and the results are discussed in Sect. 4, with overall conclusions given in Sect. 5 .

\section{Methodology}

The main approach for the study is the use of a numerical model to identify the mean circulation patterns and upwelling around Sri Lanka. There is a lack of field data from this region, and some of the available public domain data have been accessed and presented in this paper. The data include wind speed and direction data from a coastal meteorological station located at Hambantota (Fig. 1), meteorological information from ECMWF ERA interim data which were also used for model forcing, and MODIS satellite imagery (ocean colour and SST) accessed from the ocean colour website (Feldman and McClain, 2013).

\subsection{ROMS configuration and validation}

The Regional Ocean Modelling System (ROMS) is a threedimensional numerical ocean model based on the nonlinear terrain following coordinate system of Song and Haidvogel (1994). ROMS solves the incompressible, hydrostatic, primitive equations with a free sea surface, horizontal curvilinear coordinates, and a generalised terrain-following s-vertical coordinate that can be configured to enhance resolution at the sea surface or seafloor (Haidvogel et al., 2008). The model formulation and numerical algorithms are described in detail in Shchepetkin and McWilliams (2005), and have been used to simulate the circulation and upwelling processes in a range of ocean basins (e.g. Di Lorenzo et al., 2007; Dong et al., 2009; Haidvogel et al., 2008; Marchesiello et al., 2003; Xu et al., 2013).

The model grid (Fig. 1) configured for this study included the continental shelf and slope waters surrounding Sri Lanka as well as the deeper ocean, and consisted of a horizontal grid with resolution less than $2 \mathrm{~km}$, with 30 vertical layers in a terrain-following s-coordinate system. The minimum model depth was set to $-15 \mathrm{~m}$, i.e. coastal regions shallower than $15 \mathrm{~m}$ were set to $15 \mathrm{~m}$. The model was driven by direct air-sea heat and freshwater fluxes, momentum fluxes, inverted barometric effects, tide/sea levels, transport and tracers at open boundaries. The forcing data were interpolated onto the corresponding model grid points to create initial and forcing files. The model was driven with 3-hourly atmospheric forcing and daily surface heat and freshwater fluxes using ECMWF ERA interim data. The heat and freshwater fluxes were also specified using ECMWF ERA data. The net heat flux at the air-sea interface was estimated based on the balance of incoming solar radiation, outgoing long waves, and sensible and latent heat fluxes, respectively. Freshwater fluxes were estimated using precipitation and evaporation data from ECMWF ERA data, and the river inputs were ignored. HYCOM global ocean model (Bleck, 2002) daily outputs of salinity, temperature, and horizontal velocities were used to specify the open boundary section 3-D tracers and transport. Open boundary barotropic velocities were estimated by vertically averaging the eastward $(u)$ and northward $(v)$ component data, which were interpolated at the boundary sections. At open boundaries, ROMS offers a wide array of conditions. We used a combination of nudging and radiation conditions for 3-D transport and tracers at the model open boundaries. The model forcing tides were derived from the TPX07.2 global tidal model and monthly climatological mean sea levels derived from the AVISO database. The tides were provided as complex amplitudes of earth-relative sea-surface elevation and tidal currents for eight primary harmonic constituents $\left(M_{2}, S_{2}, N_{2}, K_{2}, K_{1}, O_{1}, P_{1}, Q_{1}\right)$. These harmonics were introduced in ROMS through the open boundaries elevation using the Chapman and current ellipse variables using the Flather condition (see Marchesiello et al., 2001). Model hindcast simulations were undertaken to obtain 



Figure 3. 

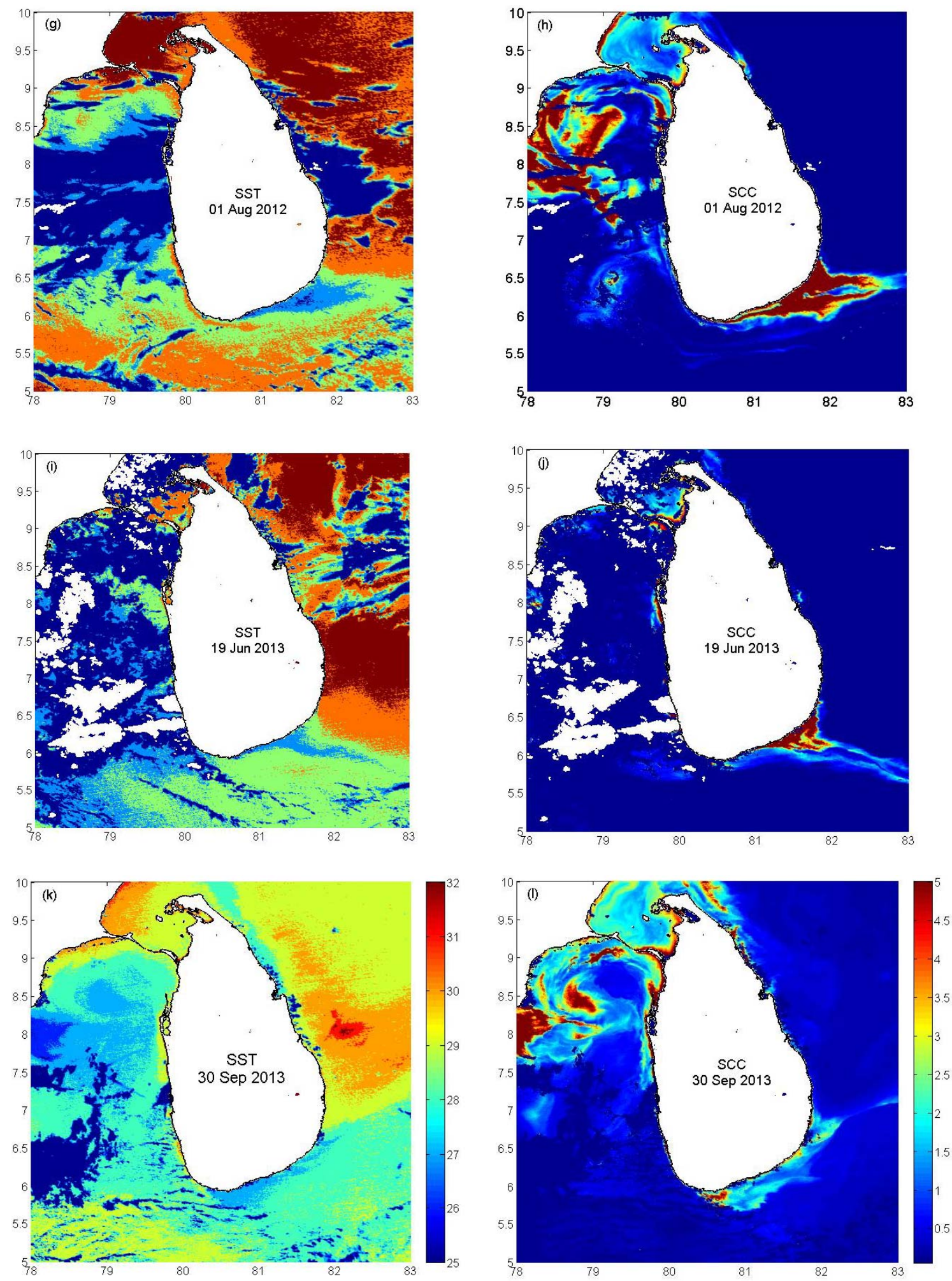

Figure 3. (a) Surface chlorophyll concentration (SCC) obtained on 12 December 2010, (b) SCC on 21 January 2011, (c) SCC on 19 January 2013, (d) SCC on 8 August 2011; (e) sea surface temperature (SST) on 19 October 2003, (f) SCC on 19 October 2003. (g) SST on 1 August 2012, (h) SCC on SST on 1 August 2012, (i) SST on 19 June 2013, (j) SCC on 19 June 2013, (k) SST on 30 September 2013, (l) SCC on 30 September 2013. The chlorophyll and temperature scales are in (k) and (l) respectively and apply to all images. 

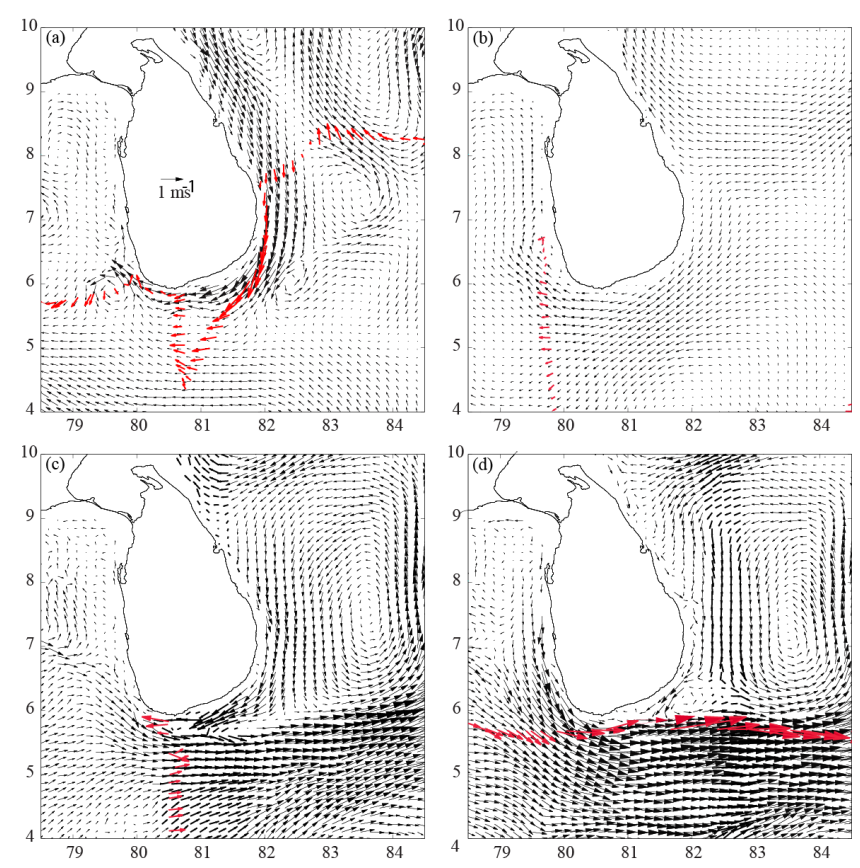

Figure 4. Comparison of the shipboard ADCP measured (red) and ROMS (black) currents at $30 \mathrm{~m}$ depth. (a) ADCP from 25 to $31 \mathrm{De}-$ cember 1997 and ROMS for 31 December 2010, (b) ADCP from 1 to 5 March 1995 and ROMS for 3 March 2011, (c) ADCP from 21 to 30 July 1993 and ROMS for 26 July 2011 and (d) ADCP from 1 to 3 August 2005 and ROMS for 3 August 2011.

optimal model results. Three-dimensional variables (salinity, temperature and velocity components) were output at daily intervals, with sea surface heights at hourly intervals.

\subsection{Experimental setup}

In addition to realistic simulations to examine the seasonal circulation patterns and upwelling, numerical experiments were also designed to address the following: (1) the role of the land-mass effect contribution to upwelling around Sri Lanka, (2) variability in the upwelling centre in response to the magnitude and direction of winds along the western and eastern sides of the island, and (3) mechanisms for the formation of the Sri Lanka Dome located to the east of Sri Lanka. In order to address (1), model simulations were undertaken, including and excluding the Coriolis term, whilst model runs with synthetic wind fields were undertaken to examine (2), with different wind stresses on the western and eastern sides of Sri Lanka. Mechanisms for the formation of the Sri Lanka Dome (3) were undertaken by forcing the model with constant westerly winds of different magnitudes $(2,4,6$ and $8 \mathrm{~ms}^{-1}$ ). A simulation was also undertaken to investigate the flow patterns in the absence of Sri Lanka. Additional model runs (not presented here) were also undertaken to investigate whether the tides played a role in the upwelling process.

\subsection{Model validation}

Model hindcasts were undertaken over a 3-year period (2010, 2011 and 2012) using realistic surface and boundary forcing (Sect. 2.1). The first year (2010) was considered as spin up, and the results presented here are from the second year (2011) of simulations, although results from the third year of the simulations are also presented (Table 2). It should be noted that 2011 was a strong La Niña year. However, comparison of the seasonal winds observed in 2011 with the previous 4 years indicated that the wind field in 2011 is not significantly different from other years. In the absence of detailed field measurements from the region, predicted surface currents and temperature distributions were compared with available data as well as with sea level data.

\subsubsection{Tide and mean sea level}

The predicted hourly sea levels at each grid point were subjected to harmonic analysis using the T-Tide MATLAB toolbox (Pawlowicz et al., 2002). To visualise and interpret model results obtained around Sri Lanka, co-tidal charts for the main tidal constituents, $M_{2}, S_{2}, K_{1}$, and $O_{1}$, were produced (not shown). The predicted amplitudes and phases from the simulation are in close agreement with measured data for four major tidal constituents (Table 1) and those of Wijeratne (2003).

\subsubsection{Large-scale circulation}

Shipboard ADCP current measurements for the region are available from the World Ocean Circulation Experiments (WOCE). However, it is important to note that there were no observations during the model simulation period (2010 and 2011). We compared the model results and observations based on the time of the year, as shown in Fig. 4. It is clear that there is good qualitative agreement between the predicted and observed currents throughout the ship tracks. The model results also reproduce some of the observed circulation features. For example, seasonal reversal of currents along the southern coast during the two monsoon periods is reproduced: during the NE monsoon, the currents flow towards the west (Fig. 4a, b), whilst during the SW monsoon, they flow to the east (Fig. 4c, d). The reversing current pattern to the east of Sri Lanka during the NE monsoon with southward currents close to the coast and northward currents further offshore is also reproduced (Fig. 4a). The model also reproduced fine-scale features that were represented in the ADCP transect such as the transition from westward to eastward currents closer to the coast (Fig. 4c).

\subsubsection{Satellite imagery}

Suspended material (such as sediment, chlorophyll, etc.) in the surface waters may be used as a passive tracer to follow flow patterns using satellite imagery (Pattiaratchi et 
Table 1. Tidal constituents at different stations along the coastline of Sri Lanka. Tide gauge data are denoted in regular font and model data are denoted in italic font. Phase refers to local time.

\begin{tabular}{lrrrrrrrr}
\hline \multirow{2}{*}{ Station } & \multicolumn{2}{c}{$M_{2}$} & \multicolumn{2}{c}{$S_{2}$} & \multicolumn{2}{c}{$K_{1}$} & \multicolumn{2}{c}{$O_{1}$} \\
\cline { 2 - 9 } & $\mathrm{a}(\mathrm{m})$ & $g^{o}$ & $\mathrm{a}(\mathrm{m})$ & $g^{o}$ & $\mathrm{a}(\mathrm{m})$ & $g^{o}$ & $\mathrm{a}(\mathrm{m})$ & $g^{o}$ \\
\hline Trincomalee & 0.180 .19 & 238252 & 0.060 .08 & 268276 & 0.070 .06 & 332338 & 0.020 .01 & 304343 \\
Batticaloa & 0.140 .14 & 235227 & 0.070 .06 & 265279 & 0.050 .04 & 330310 & 0.020 .02 & 300267 \\
Oluwil & 0.070 .05 & 230248 & 0.030 .02 & 260245 & 0.050 .06 & 332324 & 0.010 .01 & 280253 \\
Kirinda & 0.070 .06 & 9288 & 0.0560 .06 & 130112 & 0.0310 .03 & 29358 & 0.010 .01 & 1710 \\
Galle & 0.160 .17 & 5648 & 0.110 .09 & 99112 & 0.050 .06 & 2169 & 0.010 .03 & 73112 \\
Colombo & 0.180 .18 & 4548 & 0.120 .12 & 93115 & 0.070 .06 & 3248 & 0.030 .03 & 5876 \\
Chilaw & 0.180 .19 & 0450.57 & 0.110 .12 & 092114 & 0.090 .08 & 4355 & 0.030 .04 & 05886 \\
Delft Island & 0.110 .11 & 3842 & 0.040 .035 & 7784 & 0.110 .08 & 7657 & 0.050 .06 & 00624 \\
Kayts & 0.030 .02 & 6378 & 0.010 .008 & 96126 & 0.120 .09 & 61145 & 0.020 .03 & 77123 \\
Point Pedro & 0.160 .18 & 242256 & 0.090 .08 & 270245 & 0.050 .06 & 328277 & 0.010 .03 & 003347 \\
\hline
\end{tabular}
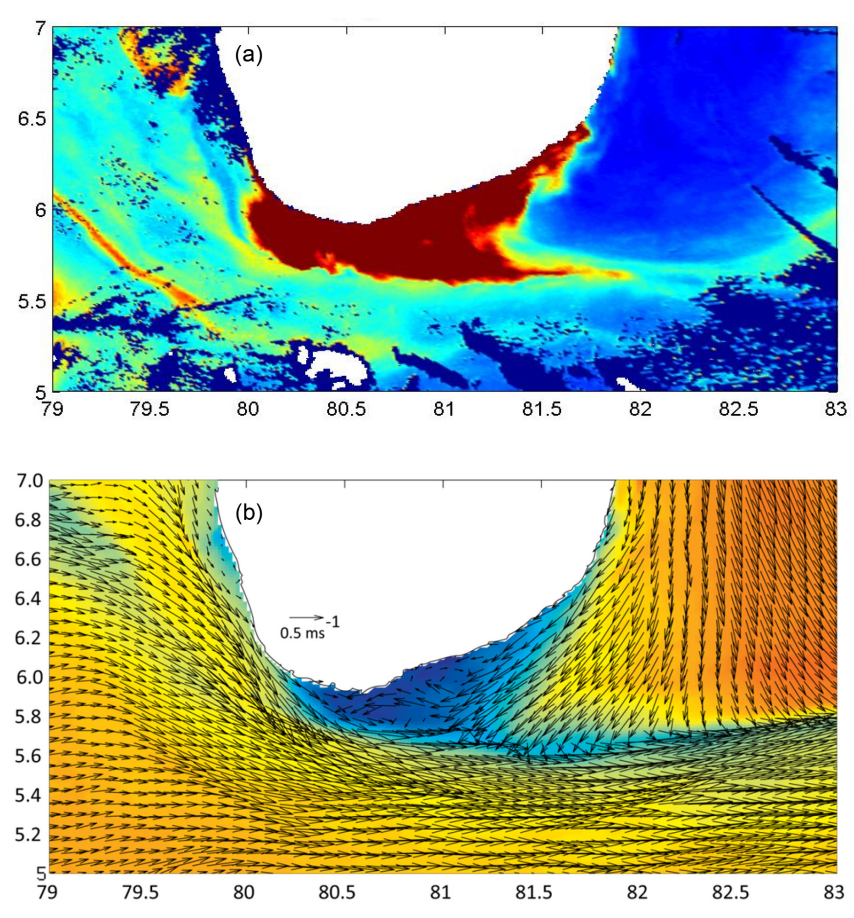

Figure 5. Typical summer upwelling frontal features around the southern part of Sri Lanka obtained on 12 October 2003: (a) satellite-derived surface chlorophyll concentration, and (b) predicted near-surface current vectors and temperature. Note that the colour scales are given in Fig. 3.

al., 1987). In regions of upwelling (for example, see Fig. 3), there is also a correspondence between regions of higher surface chlorophyll concentrations (SCC) and lower sea surface temperatures (SST). Thus, ocean colour imagery may be used qualitatively to validate numerical model outputs. Comparison between model-predicted SST and satellite-derived SCC indicates that the model reproduced observed patterns, particularly the higher chlorophyll "tongue" feature, and sharp fronts (Fig. 5).

\section{Results}

\subsection{The wind field}

The monsoon and inter-monsoon periods occur at similar times during the year. However, there is an inter-annual variability in the onset of these climatic events, and thus the timing of each monsoon can vary by up to 1-2 months. Wind data recorded in 2010 from a coastal meteorology station located along the southeastern coast of Sri Lanka (Hambantota, Fig. 1) reflect changes in the wind field, in accordance with the monsoons (Fig. 6): winds blew from between the north and east $\left(0-90^{\circ}\right)$ from December to April, whilst the winds were predominantly from the southwest and west $\left(225-270^{\circ}\right)$ between April and November (Fig. 6b). Wind speeds were $\sim 8 \mathrm{~ms}^{-1}$ between mid-January and mid-March, corresponding to the peak of the NE monsoon: less than $6 \mathrm{~ms}^{-1}$ between mid-March and mid-May (waning NE monsoon and first inter-monsoon), increasing to more than $6 \mathrm{~ms}^{-1}$ from June until October, reflecting the SW monsoon, and decreasing to less than $6 \mathrm{~ms}^{-1}$ during the second inter-monsoon period in mid-November.

In addition to the temporal changes in the wind field, there is also significant spatial distribution, as revealed by the ECMWF ERA interim data (Fig. 7). One of the factors influencing the spatial wind field is the local land topography of Sri Lanka and southern India. Coastal regions around Sri Lanka are relatively flat and surround the elevated central region that increases to a maximum elevation of $2500 \mathrm{~m}$. Similarly, southern India consists of elevated terrain that exceeds $1000 \mathrm{~m}$ (Luis and Kawamura, 2000). During the NE monsoon (Fig. 7a, f), winds are predominantly from the northeast across the study region, with stronger winds in the Gulf of Mannar (Fig. 1) as a result of the local land topography. Here, the northeasterly winds are funneled through the elevated topography between southern India and Sri Lanka, resulting in strong winds over the Gulf of Mannar (Luis and Kawamura, 2000). Off the southern coast of Sri Lanka, the winds 

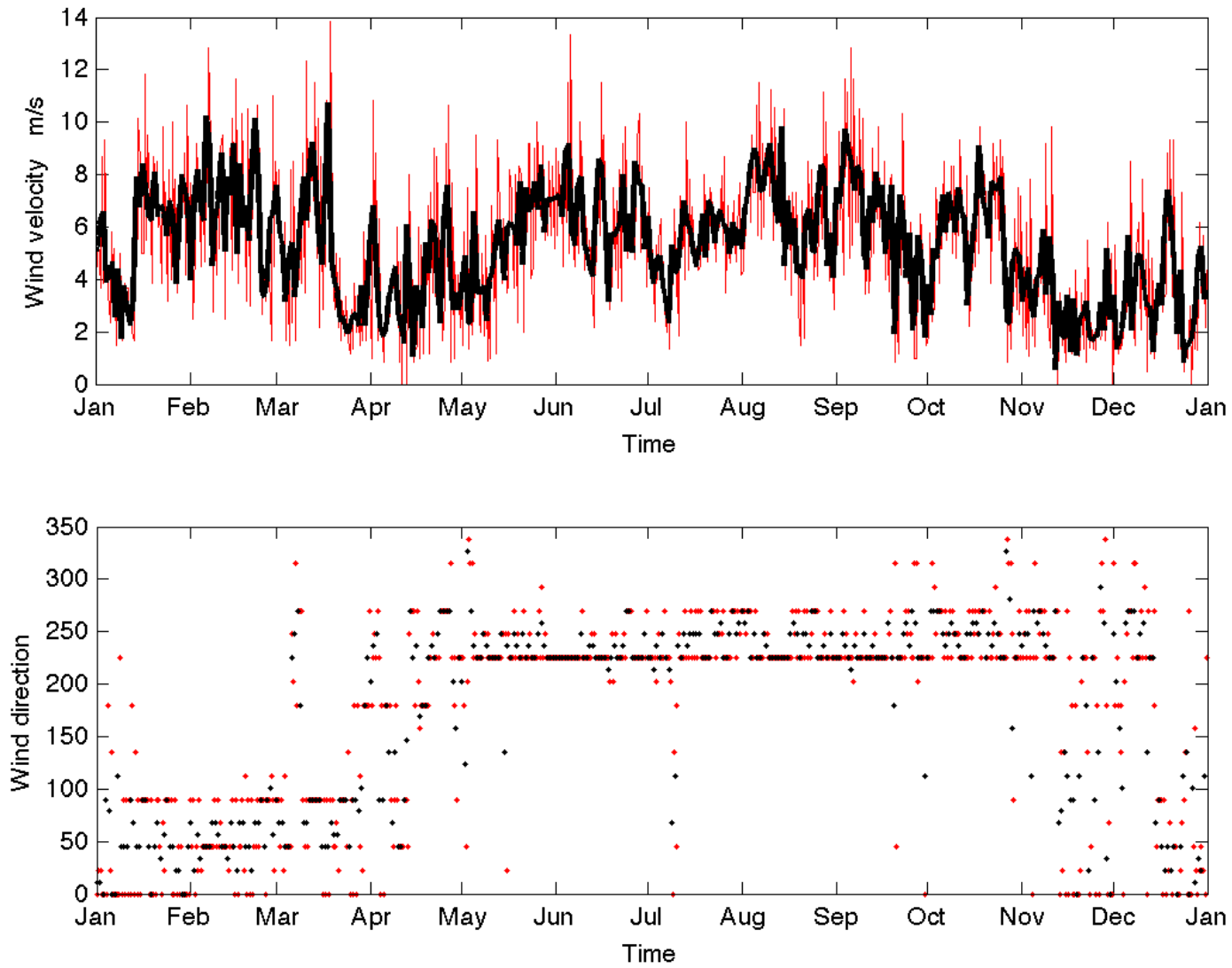

Figure 6. Time series for wind speed and direction ( 0 winds from the north) for Sri Lanka in 2010 . The red line and dots indicate daily data collected at 08:30 and 17:30 LT and the black line and dots indicate the daily averaged data. Data were obtained from the Hambantota meteorological station, southeastern Sri Lanka.

are weaker and are mainly offshore during the NE monsoon (Fig. 7a, f). During the first inter-monsoon, the eastern coast of Sri Lanka experiences onshore winds (easterly) with northeasterly winds along the western coast, and winds off the southern coast remaining offshore (Fig. 7b). Along the western and southern coasts of Sri Lanka, during the SW monsoon, the winds are westerly (Fig. 7c, d and e) and, due perhaps to the local topography, they veer northwards off the eastern side of the island (southwesterly winds). As such, both the temporal and spatial wind fields influence the ocean circulation patterns around the island.

\subsection{Seasonal circulation}

\subsubsection{Satellite imagery}

The seasonal circulation around Sri Lanka was examined through the use of surface chlorophyll concentration (SCC) climatology data (resolution of $4 \mathrm{~km}$ from Feldman and McClain, 2013) as a passive tracer and to understand seasonal variability in surface chlorophyll concentrations.

In January, the Northeast Monsoon Current (NMC) flows from east to west (Fig. 8a). This is reflected in the SCC data with slightly higher concentrations to the west of Sri Lanka. However, the more pronounced feature is the "stirring" caused by the NMC flowing from east to west past the Maldives island chain, with enhanced SCC to the west of the island chain. During this period, the monsoon drift is shallow and will generally only have a minimal effect on the waters below the thermocline (Wyrtiki, 1973). In March, during the monsoon transition period, SCC decreased to less than $0.20 \mathrm{mgm}^{-3}$ (Fig. 8b) in the whole study region. There is an absence of a "concentration wake" in the vicinity of the Maldive Islands, indicating weak currents lacking unidirectionality in this region. Similar conditions were observed in April (not shown). In May, during the onset of the SW monsoon (Fig. 7c), a band of high SCC $\left(\sim 2.5 \mathrm{mgm}^{-3}\right.$ ) water was present along the southern coast of Sri Lanka (Fig. 8c) and also in the Gulf of Mannar. SCC levels along the southern coast were 10 times higher than they were in April, but low concentrations were present to the east of Sri Lanka. In July, enhanced SCC to the east of the Maldive islands and the plume of elevated SCC to the southeast of Sri Lanka confirmed the eastward flow of the Southwest Monsoon Current (Fig. 8). In June (not shown), the high SCC patch off southern India begins to extend to the east across the entrance 
(a) January

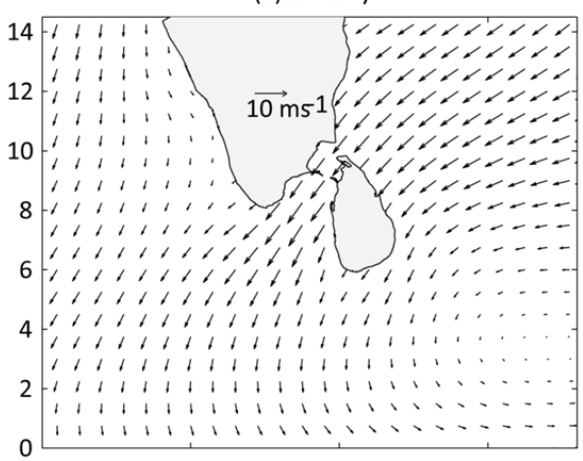

(c) May

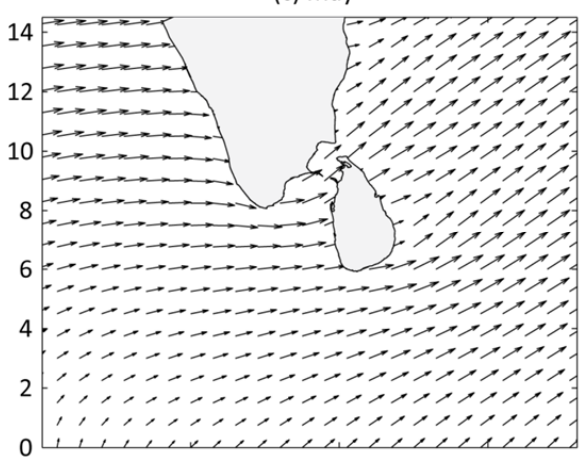

(e) September

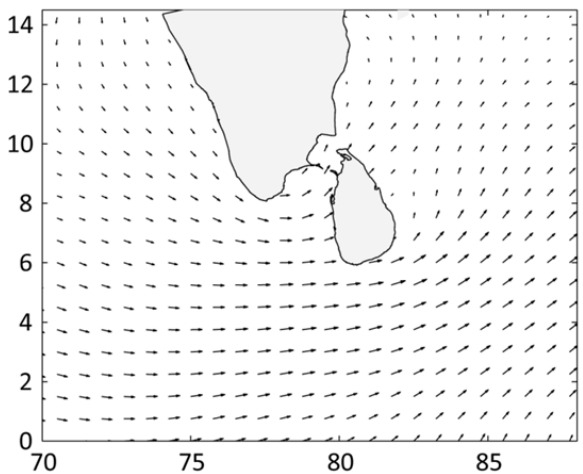

(b) March

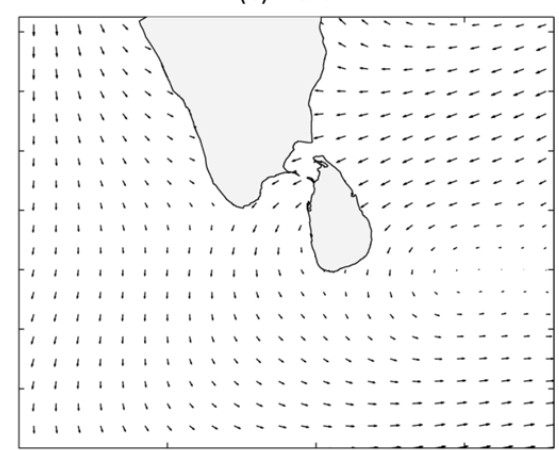

(d) July

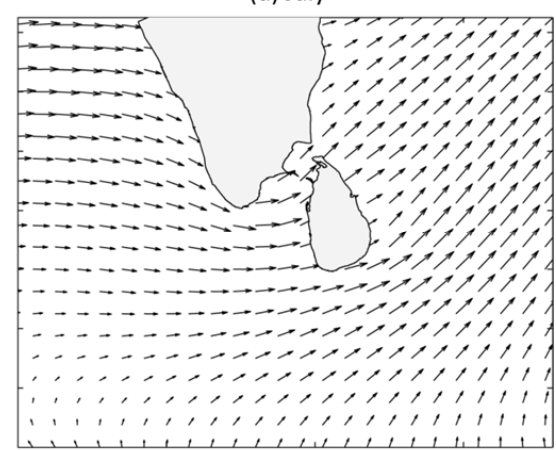

(f) November

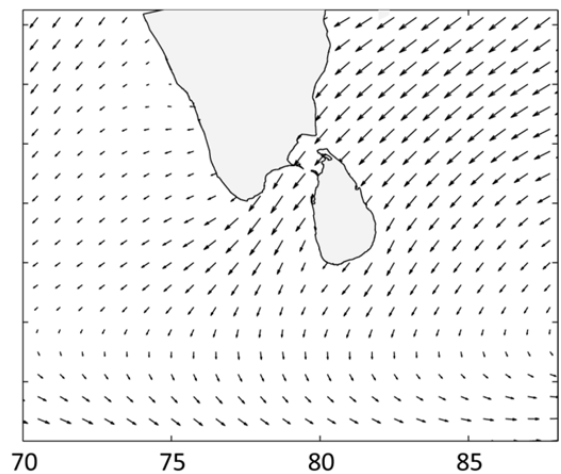

Figure 7. Bi-monthly wind speed and direction for Sri Lanka in 2011 from ECMWF ERA interim data. Each plot represents a bi-monthly average, with the length of the arrow correlating with speed. (a) January (northeast monsoon), (b) March (first inter-monsoon), (c) May, (d) July, (e) September (southwest monsoon) and (f) November (second inter-monsoon).

to the Gulf of Mannar, whilst the surrounding areas experienced decreased SCC. In July, the high SCC plume generated by the SW monsoon current flowing past the Maldive Islands merged with the high SCC patch off southern India and the higher SCC waters off the western coast of Sri Lanka (Fig. 8d). The SCC is $\sim 5 \mathrm{mgm}^{-3}$ along the western and southern coasts of Sri Lanka. A plume of higher SCC water originating from the southern coast of Sri Lanka extended to the east and shows evidence of an eddy - most likely the Sri Lankan Dome (Fig. 2). There is also a band of lower SCC water adjacent to the eastern coast of Sri Lanka, which is due to the southward flow of water along this coast at this time of year. In September, the SCC patterns were similar to that in July (Fig. 8e), except that the maximum SCC was lower in the range of $0.20=-0.40 \mathrm{mgm}^{-3}$ and extended over a larger area, particularly to the south and east of Sri Lanka. In November, the SCC levels decreased almost to those observed in January, the difference being that the plume from the Maldive Islands was present to the east, indicating that the SMC was still flowing eastwards (Fig. 8f).

In general, chlorophyll a concentrations around Sri Lanka were relatively lower during the NE monsoon compared to the SW monsoon (Kabanova, 1968). This seasonality is maintained year to year, but with inter-annual variability (Fig. 9). A Hovmöller diagram of monthly mean SSC between the southern coast of Sri Lanka $\left(6^{\circ} \mathrm{N}\right)$ and the Equator 

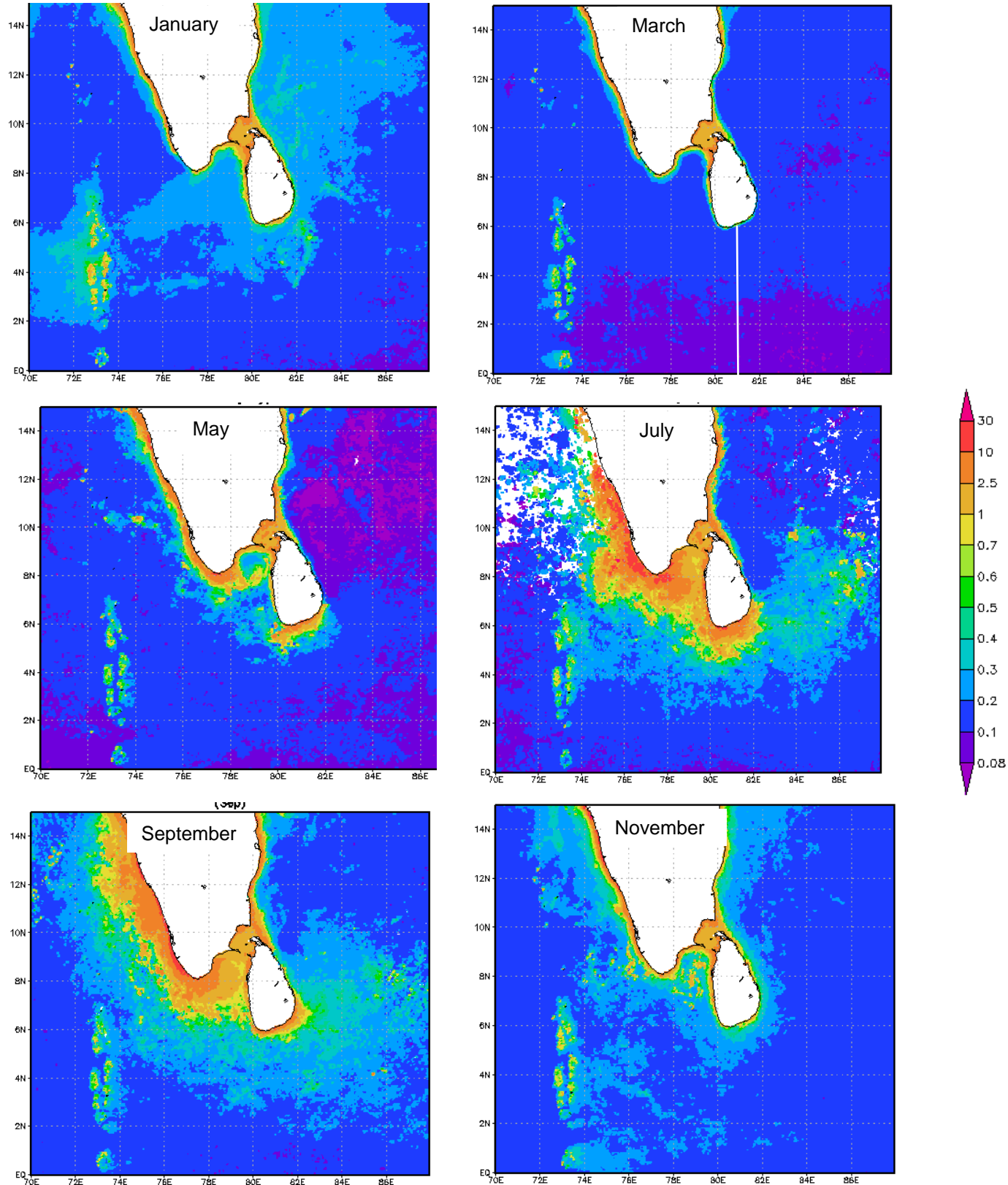

Figure 8. Climatological monthly mean surface chlorophyll concentrations around Sri Lanka: (a) January, (b) March, (c) May, (d) July, (e) September and (f) November. The white line in March represents the location of the data extracted for the Hovmöller diagram in Fig. 9.

indicates higher values closest to the Sri Lankan coast extending $\sim 270 \mathrm{~km}$ offshore on average. In 2002 and 2006, the influence of this upwelling can be observed extending to the Equator. Although interannual variability is not within the scope of this paper, it is interesting that 2002 and 2006 reflect El Niño and positive Indian Ocean dipole years (Sreenivas et al., 2012).

\subsubsection{Numerical modelling}

Numerical model results reproduce the general patterns identified in previous studies (Fig. 2) and from ocean colour imagery (Fig. 8). The seasonal mean currents show significant spatial variability due to the spatial and temporal changes in the wind climate (Fig. 10). This is evident when comparing the mean currents during the NE monsoon (Fig. 10a) and the instantaneous currents at the end of December (Fig. 4a, b). The reversing currents to the south of Sri Lanka, easterly during the SW monsoon and westerly during the NE monsoon, 


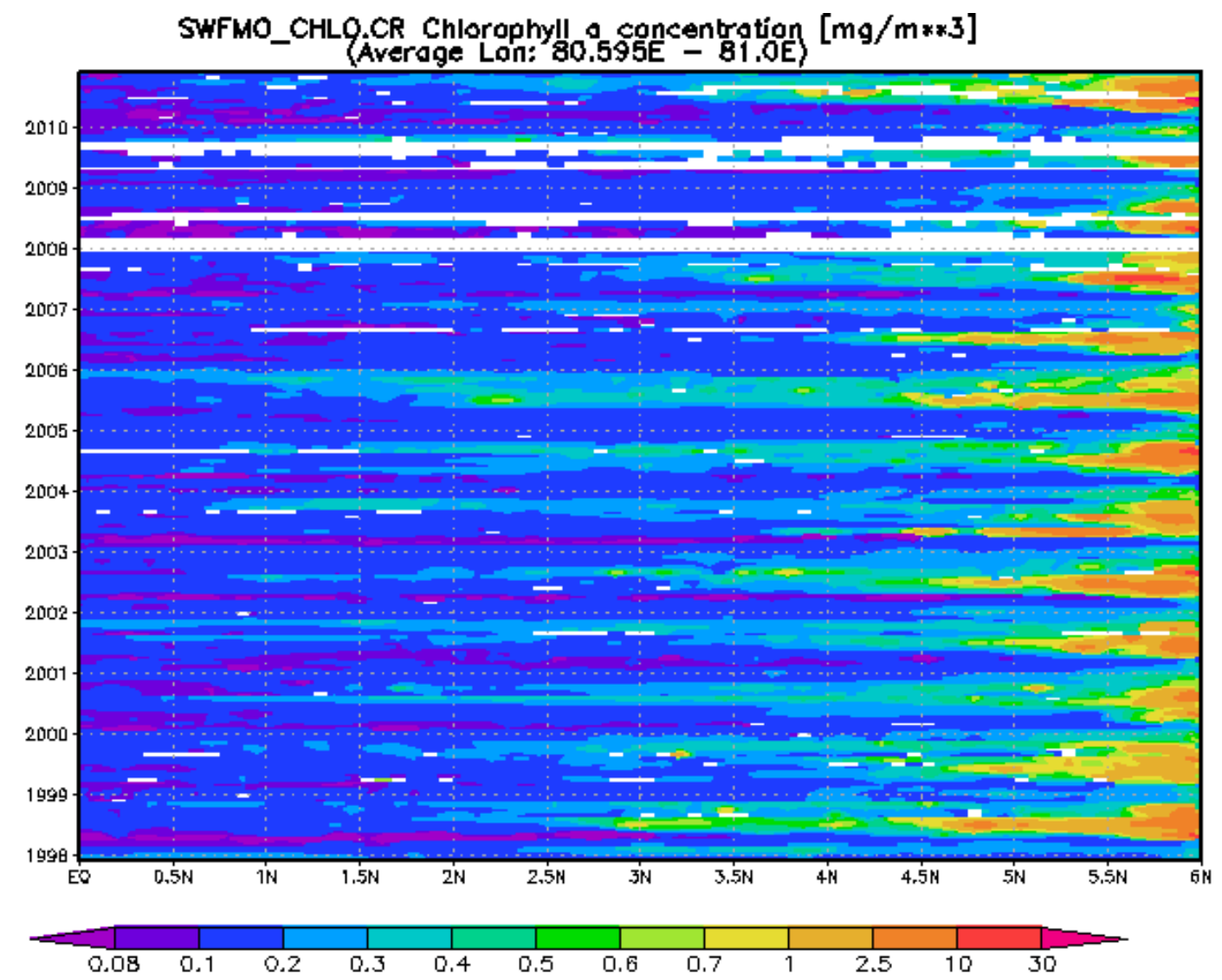

Figure 9. Hovmöller diagram displaying seasonality and interannual variability of surface chlorophyll concentrations off the southern coast of Sri Lanka. The location of the transect is shown in Fig. 8.

Table 2. Volume transport of water between Sri Lanka and the Equator along $80.5^{\circ} \mathrm{E}$ for the three simulation years.

\begin{tabular}{lll}
\hline $\begin{array}{l}\text { Simulation } \\
\text { year }\end{array}$ & $\begin{array}{l}\text { Southwest Monsoon } \\
\text { Current (SMC) }\end{array}$ & $\begin{array}{l}\text { Northeast Monsoon } \\
\text { Current (NMC) }\end{array}$ \\
\hline 2010 & $10.25 \mathrm{~Sv}$ & $8.27 \mathrm{~Sv}$ \\
2011 & $12.78 \mathrm{~Sv}$ & $10.69 \mathrm{~Sv}$ \\
2012 & $11.36 \mathrm{~Sv}$ & $9.87 \mathrm{~Sv}$ \\
Mean & $11.46 \mathrm{~Sv}$ & $9.61 \mathrm{~Sv}$ \\
\hline
\end{tabular}

are reproduced by the model. The currents during the SW monsoon are stronger than those during the other seasons, reflecting the stronger winds during this period (Fig. 10c). Schott and McCreary (2001) estimated that off southern Sri Lanka (north of the Equator), transport rates resulting from the SMC and NMC were $8 \mathrm{~Sv}$ and $12 \mathrm{~Sv}$ respectively, with SMC transport rates lower than those for the NMC. The numerical model output indicates transport rates ranging from 10.25 to $12.78 \mathrm{~Sv}$ (mean $=11.5 \mathrm{~Sv}$ ) and from 8.27 to $10.69 \mathrm{~Sv}$ (mean $=9.6 \mathrm{~Sv}$ ) for the SMC and NMC respectively (Table 2). The estimate for the NMC transport is similar to that reported by Schott and McCreary (2001), but SMC transport is higher, as expected due to the stronger winds experienced during this period.

During the NE monsoon, currents along the eastern coast of Sri Lanka flow southwards closer to the coast and northwards further offshore, separated by a shear zone (Fig. 4a, b). The presence of the shear zone is confirmed by a shipborne ADCP transect (Fig. 4a). The currents closer to the shore follow the coastline, flowing to the west along the southern coast and northward along the western coast (Fig. 10a; Fig. 4a, b). Currents in the Gulf of Mannar flow towards the southwest and mirror the direction of the wind (Fig. 10a). During the first inter-monsoon, current speeds decrease (Fig. 10b); currents along both the eastern and western coasts were converging off southern Sri Lanka (south of $\sim 6.5^{\circ} \mathrm{N}$ ). The presence of the Sri Lanka Dome centered at $84^{\circ} \mathrm{E}$ and $8^{\circ} \mathrm{N}$ can be identified. Strong northward currents along the northeastern coast extending along the southern Indian coastline are predicted. This flow pattern is similar to that shown on satellite images by Legeckis (1987) postulating a western boundary current in the Bay of Bengal.

Under SW monsoon conditions, currents are higher across the entire region, particularly along the southern and southeastern coasts of Sri Lanka (Fig. 10c). As a result, the Sri 

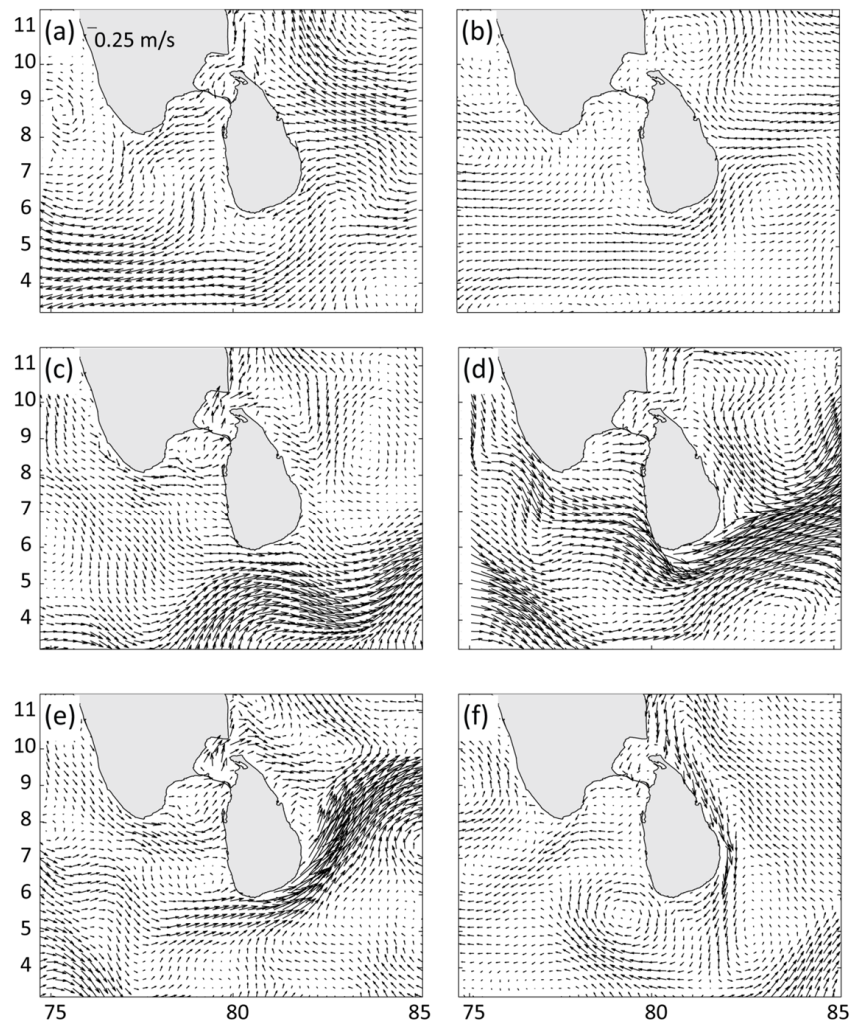

Figure 10. Seasonal surface circulation from ROMS: (a) January (northeast monsoon), (b) March (first inter-monsoon), (c) May, (d) July, (e) September (southwest monsoon) and (f) November (second inter-monsoon).

Lanka Dome shifts to the north - now centered at $84^{\circ} \mathrm{E}$ and $9.5^{\circ} \mathrm{N}$. Southward flowing water along the eastern coast converges with water eastward of the SMC. There is also a stronger band of currents flowing past the southern tip of India and west of Sri Lanka (Fig. 10c), which explains the merging of the SCC between the southern regions of the Indian coast and Sri Lanka (Fig. 8d). The weakest currents are predicted during the second inter-monsoon, with no evidence of the Sri Lanka Dome (Fig. 10d).

Flow patterns such as those described in Fig. 10 provide no indication of regions and periods of coastal upwelling around Sri Lanka. Therefore, the model-predicted sea surface temperature (SST) and flow fields were examined at shorter timescales, with the assumption that cooler waters (compared to the surrounding water) represented upwelling. Analysis of model output revealed that upwelling occurs on a seasonal basis and/or during shorter period sporadic events along different parts of the coastline. This is highlighted in Fig. 11, with the corresponding wind fields shown in Fig. 12. During the NE monsoon, cooler SSTs were observed along the western and southern coasts, with warmer water along the eastern coast of Sri Lanka (Fig. 11a). The latter is due to the downwelling regime in this region, with onshore winds (Fig. 12a)
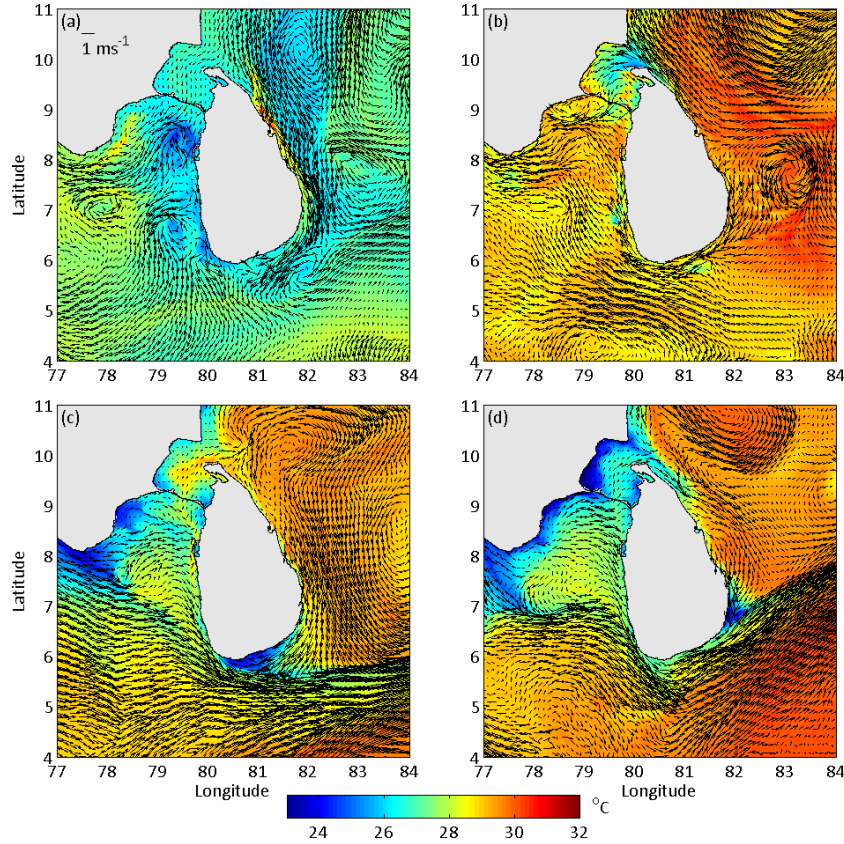

Figure 11. Predicted near-surface current vectors plotted on the surface temperature showing major upwelling regions around Sri Lanka: (a) 16-20 January 2011, (b) 10-14 April 2011, (c) 1216 July 2011 and (d) 18-22 August 2011.

during the NE monsoon reflected in a band of narrow warm southward moving water. Colder waters were found in regions of divergence in the flow field, where there was mainly offshore transport of water (Fig. 11a), reflecting the possibility that perhaps processes other than wind-driven upwelling may be responsible for the upwelling. There was negligible colder surface water present during the first inter-monsoon period, except perhaps along the extreme north of Sri Lanka (Fig. 11b). The southern coastal regions of both India and Sri Lanka experienced colder SST throughout the SW monsoon, indicating strong upwelling during this period (Figs. 11c, d). There was also advection of colder water from the southern tip of India to the western coast of Sri Lanka during the SW monsoon (Fig. 11c, d). The most notable feature is the shape of the cold water regions to the south and southeast of Sri Lanka (Fig. 11c, d, respectively). This shape is clearly visible on satellite images as a result of the associated higher SCC (Figs. 2 and 5), and occurs in regions of convergence: in July 2011 (Figs. 3 and 11c), water flowing southwards along both the eastern and western coasts converges to the south and is transported offshore, resulting in a colder water patch near the coast. In August, this colder water patch migrates to the east, and is present off the southeastern coast of Sri Lanka (Fig. 11d). This feature is very similar to that observed on the August 2012 satellite image (Fig. 3c, d). These features indicate that wind-driven upwelling through Ekman dynamics is most likely not responsible for upwelling along the southern coast of Sri Lanka. 

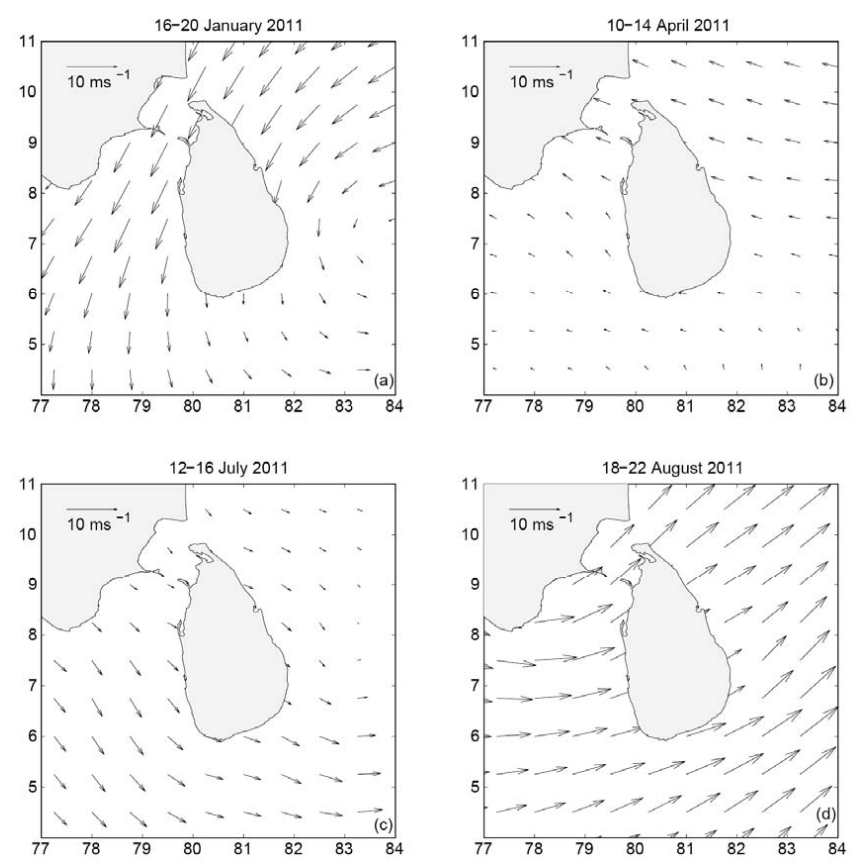

Figure 12. Wind fields corresponding to the predicted currents shown in Fig. 11.

Time series of volume transport along a transect to the south of Sri Lanka and SST at three locations over one year (2012) indicated the seasonal variability (Fig. 13). Between January and April (NE monsoon and the first intermonsoon), the volume transport was to the west, with rates up to $0.08 \mathrm{~Sv}$ and intermittent reversal of the currents to the west (Fig. 13b). The flow was generally towards the east between May and October (SW monsoon and the second intermonsoon) before reversing towards the west during November and December (Fig. 13b). During the SW monsoon, the transport increased from June to the end of July, when it reached a maximum of $0.23 \mathrm{~Sv}$ and then generally decreased in strength (Fig. 13b). The monsoon pattern was clearly reflected in the SST time series (Fig. 13c), with relatively lower SST in January/February (NE monsoon) and higher SST between March and April (first inter-monsoon), with the temperatures decreasing in May and then being relatively low between June and September (SW monsoon), and higher values between October and November (second inter-monsoon) and then decreasing during December (NE monsoon). Although the SST at all three locations was very similar during the inter-monsoon period, with relatively higher values, there were differences during the monsoon period due to upwelling (cooler waters). In January/February (NE monsoon), the waters to the southwest were relatively cooler when compared to the southeast, whilst between June and September (SW monsoon), the waters in the southeast were cooler (Fig. 13c). This shift in the colder water may indicate a migration of the upwelling centre from the southwest to southeast between the two monsoon periods.

\subsection{Temporal (10-day) variability}

In order to assess the shorter period spatial variability of surface circulation and upwelling around Sri Lanka, model outputs for surface currents and temperature averaged over a 10-day period were examined. Initially, during the NE monsoon (January 2011), southward currents flowed along both the eastern and western coasts of Sri Lanka, with easterly currents along the southern coast (Fig. 14a). The currents appear to converge along the southeastern corner, as indicated by the presence of colder water. Over the next 10 days, the currents along the eastern coast increased due to stronger winds, and this was accompanied by a reversal in the currents along the southern coast, which flow eastwards, causing the convergence zone (and colder water due to upwelling) to shift towards the southeast (Fig. 14b). During the subsequent 10-day period, there is colder water along the entire western coast of Sri Lanka including the Gulf of Mannar, due to upwelling and a contribution through cooling due to airsea fluxes (e.g. Luis and Kawamura, 2000). Analysis of scatterometer (NSCAT) winds by Luis and Kawamura (2000) indicated a 15-day periodicity in the wind field, and these changes in the circulation patterns may reflect the temporal changes associated with the wind field. Shorter period spatial variability during January and July is shown in Figs. 9 and 10, respectively. ROMS simulations suggest that a small change in the direction of the currents incident on the island can change the nature of the current patterns around the island and the location of the upwelling centre. This will be analysed further in the next section.

During the SW monsoon, the eastward flowing SMC dominates the region. However, there is a similarity in the current fields to those observed during the NE monsoon: currents along both the western and eastern coasts flow southwards, with a region of convergence either along the southern or southeastern coast of Sri Lanka (Fig. 15). At the beginning of the sequence (12 July 2012), the currents along both coasts converge at the centre of the southern coast of Sri Lanka (Fig. 15a), and over the subsequent 40-day period, this convergence zone progressively migrated along the southern coast to the eastern coast (Fig. 15b-d). As a result, the cold water region associated with the convergence of the currents also migrated to the east. The SST patterns predicted by the model were very similar to those observed in the satellite imagery (cf. Figs. 15 and 3c, d).

A similar time sequence in 2012 also indicated a similar process (Fig. 16). Initially, the currents were strongly towards the east associated with the well-established SMC, and southerly flow along the eastern coast was weak. The surface currents and SST shown in Fig. 16a and b corresponded to the peak of the SMC in August 2012 (Fig. 13b). However, at the end of August, the flow along the eastern coast 

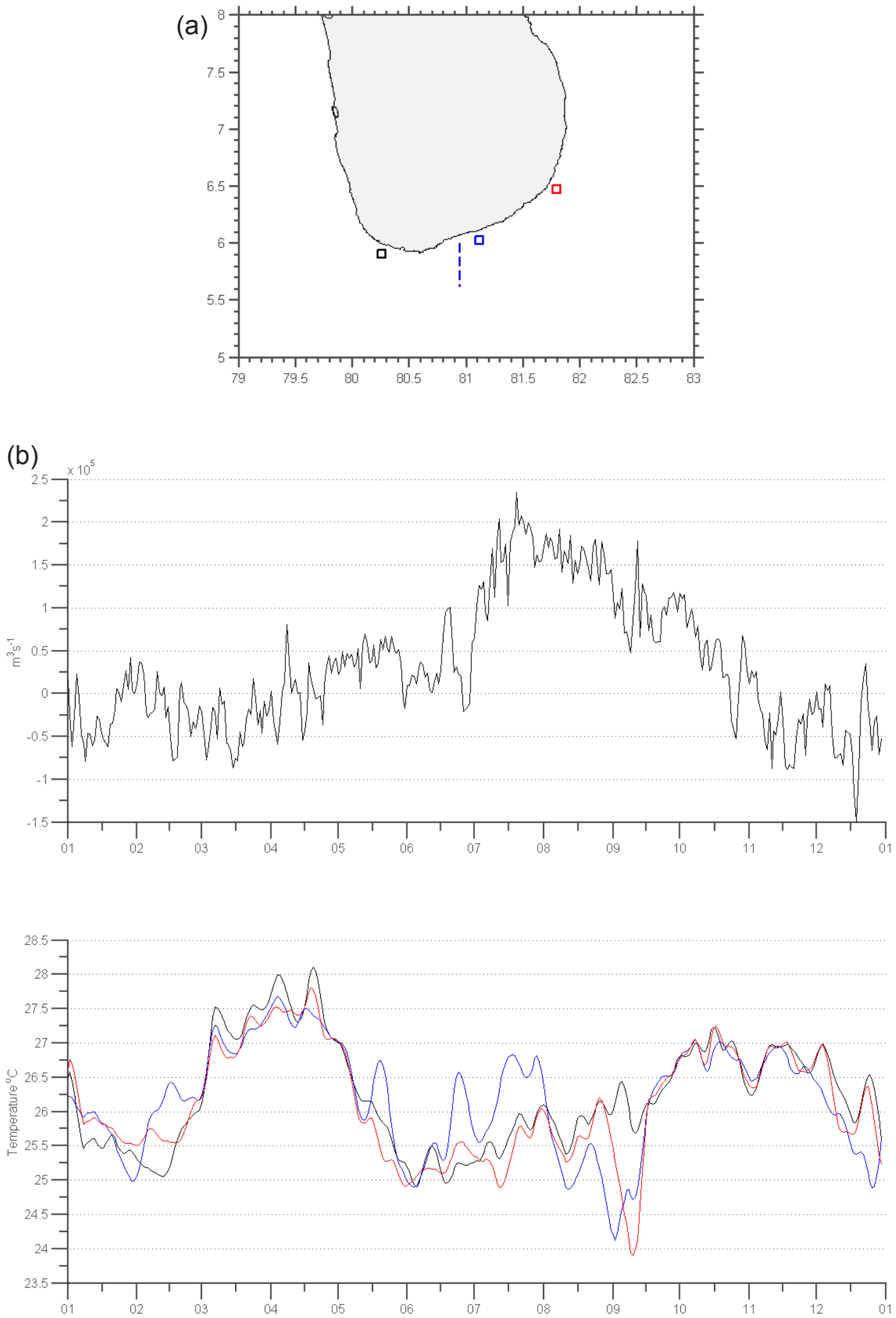

Figure 13. Time series of volume transport across a transect located to the south of Sri Lanka (b) and sea surface temperature (SST) time series along the southwestern (black), southern (blue) and southeastern (red) coasts of Sri Lanka. Locations of the volume transport time series transect and the SST time series are shown in (a). 

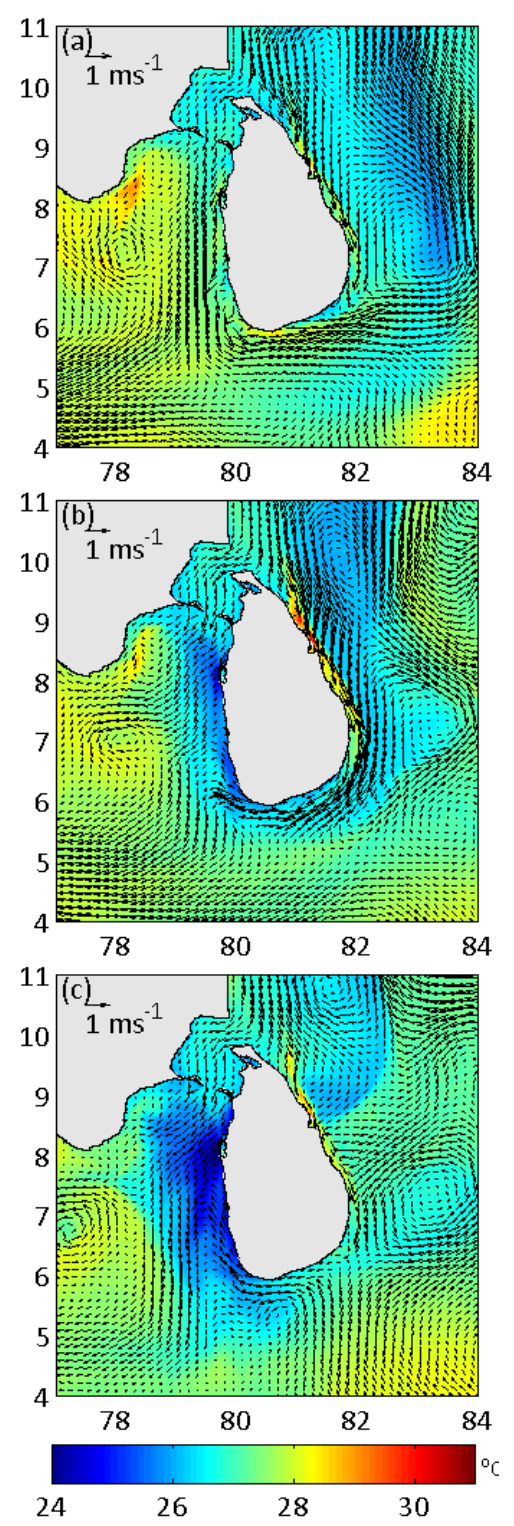

Figure 14. Predicted near-surface current vectors plotted on the surface temperature showing sporadic upwelling in (a) 1-10 January 2011, (b) 11-20 January 2011 and c) 21-31 January 2011.

strengthened, and a convergence zone was present along the southern coast, with colder temperatures (Fig. 16c). This is also reflected in the time series of SST, where the SST at the southern and southeastern stations decreased during this period (Fig. 13c). In the subsequent 10 days, the convergence zone migrated to the east (Fig. 16d) and was reflected in the time series (Fig. 13b).

The model results and satellite imagery for both the NE and SW monsoon periods indicated that, in general, southward currents flow along both coasts of Sri Lanka, resulting in a convergence region along the southern half of the island. During the NE monsoon, this convergence region migrates to the west (Fig. 14), whilst during the SW monsoon,
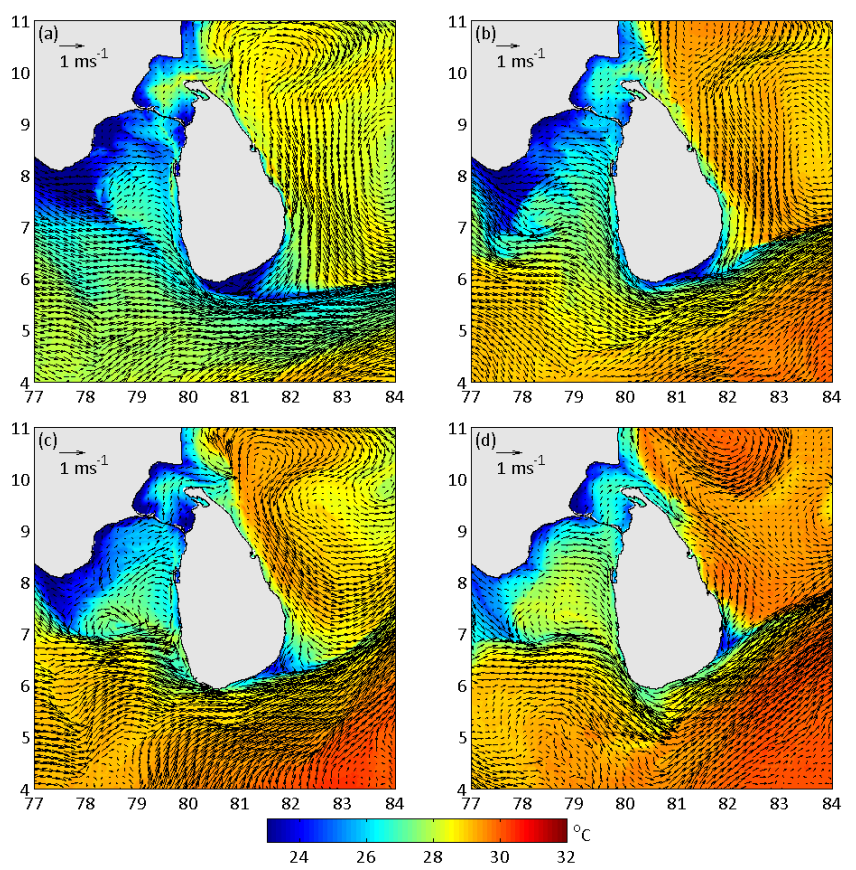

Figure 15. Predicted near-surface current vectors plotted on the surface temperature showing migration of the upwelling centre to the east: (a) 12 July 2011, (b) 22 July 2011, (c) 2 August 2011 and (d) 12 August 2011.

the convergence region migrates to the east (Figs. 15 and 16). Idealised model runs were undertaken to investigate the mechanisms causing this migration, which was hypothesised to be due to different wind stresses on each of the coasts. Three idealised model runs were undertaken with constant northerly winds as follows: (1) wind stress of $0.28 \mathrm{~Pa}$ off the eastern coast and $0.14 \mathrm{~Pa}$ along the western coast; (2) wind stress of $0.28 \mathrm{~Pa}$ along both coasts; and (3) wind stress of $0.14 \mathrm{~Pa}$ off the eastern coast and $0.28 \mathrm{~Pa}$ along the western coast (i.e. the opposite of 1). The results indicated that when the wind stress was equal along both coasts, the upwelling region was located directly off the southern coast (Fig. 17), whilst when the wind stress was stronger on the western (eastern) coast, the upwelling region migrated to the east (west). Thus, the location of the upwelling appears to be controlled by the relative strengths of the winds along each coast, which changes with season due to the changing monsoon. However, the surface currents and upwelling were much stronger during the SW monsoon compared to during the NE monsoon, due to the increased wind strengths (see also Fig. 13).

\subsection{Sri Lanka Dome}

One of the major features observed during the SW monsoon period is the presence of the Sri Lanka Dome (SLD, Fig. 2). Here, the SMC flows eastward along the southern coast of Sri Lanka and creates a recirculation in the lee (east) of Sri 

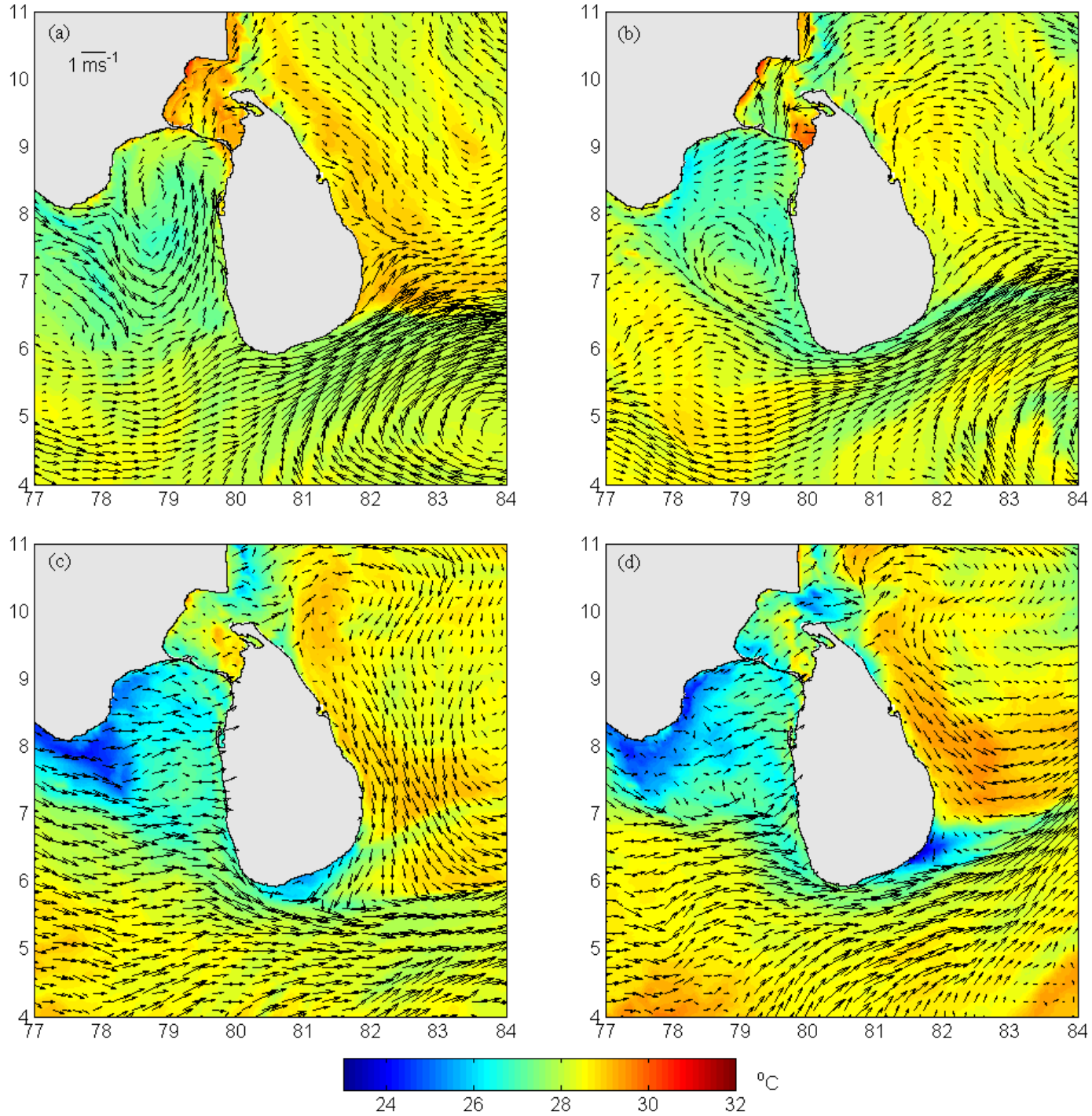

Figure 16. Predicted near-surface current vectors plotted on the surface temperature showing the development of upwelling during the southwest monsoon in 2012: (a) 10 August 2012, (b) 20 August 2012, (c) 1 September 2012 and (d) 10 September 2012.

Lanka, with the western arm creating a southward current along the eastern coast. The features of the dome were identified in the satellite climatology (Fig. 8d) and in the numerical model output (Fig. 10c). Analysis of the climatological thermal structure along $85^{\circ} \mathrm{E}$ by Vinayachandran and Yamagata (1998) indicated well-developed upward doming isotherms, and they attributed the presence of the dome to open ocean Ekman pumping. The SLD is analogous to flow patterns in the lee of headlands and islands, with the island of Sri Lanka acting as a headland interacting with the eastward flowing SMC (e.g. Pattiaratchi et al., 1987). A series of idealised model runs were undertaken to examine the hypothesis that the SLD is formed through the interaction between the SMC and the topography. Here, 15-day model runs with constant westerly winds of 2, 4, 6 and $8 \mathrm{~ms}^{-1}$ were undertaken. An additional model was also undertaken with the removal of the land mass of Sri Lanka. Here, water depths less than $500 \mathrm{~m}$ surrounding Sri Lanka and the land area were set to $500 \mathrm{~m}$ water depth. The wind speeds selected were based on observed winds (Fig. 6), and westerly winds were prescribed in the model, as this was the main direction of winds to the west of Sri Lanka during the SW monsoon (Fig. 7). The results indicate that, under wind forcing, a recirculation occurred in the lee of Sri Lanka. In contrast, for the case where the Sri Lanka land mass was absent, there was no re-circulation in the lee of the island. The recirculation strengthened (increased in vorticity) with an increase in the wind speed, although the location of the centre remained at the same location around $84^{\circ} \mathrm{E}$ and $7-8^{\circ} \mathrm{N}$, with a slight migration to the east with increasing wind stress. These results indicate that the primary formation mechanism of the SLD is the interaction between the SMC and the land mass 


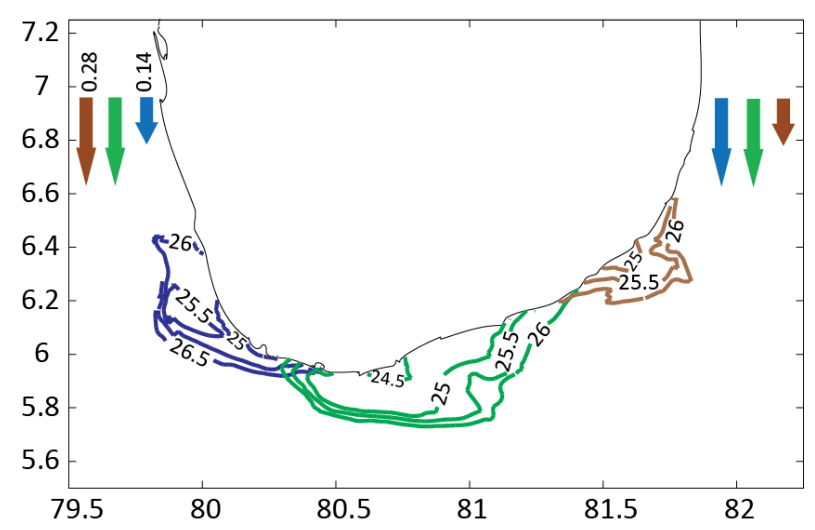

Figure 17. Predicted locations of the convergence region and associated upwelling region with respect to different stresses along each coast. The contours represent sea surface temperature (SST) with the colour representing the magnitude of the wind stress.

of Sri Lanka. This does not rule out the possibility that Ekman pumping may play a role in strengthening the dome.

\section{Discussion}

The seasonal and shorter term ( $\sim 10$ days $)$ changes in the surface circulation and upwelling patterns around Sri Lanka were examined using satellite imagery (mainly ocean colour) and a high spatial resolution numerical model (ROMS) configured to the study region and forced with ECMWF interim data. The model reproduced all of the documented major circulation features in the region: reversing monsoon currents in response to the changing wind field and the Sri Lanka Dome. The model predictions of sea surface temperature patterns were similar to those observed by satellite imagery. Model output was used to update the transport rates of the SMC and NMC between Sri Lanka and the Equator. Using a current meter array located to the south of Sri Lanka, Schott et al. (1994) estimated transport rates of 8 and $12 \mathrm{~Sv}$ for SMC and NMC. These values are contradictory in that with stronger SW monsoon winds it would be expected that SMC transport rates are higher than those for the NMC. The numerical model output indicates mean transport rates of 11.5 and 9.6 Sv for SMC and NMC respectively (Table 2). The values for the NMC are similar to those estimated by Schott et al. (1994), but that for the SMC is now higher. It should be noted that the estimates by Schott et al. (1994) were through the analysis of moored current meters, which did not sample the top $30 \mathrm{~m}$ of the water column.

The predicted flow patterns around Sri Lanka, created through the interaction between SMC and the island leads, are indicative of flow patterns observed in other regions both in deep and shallow water; however, due to the reversing flow, two distinct patterns can be identified:
1. During the SW monsoon, the SMC interacts with the island, which acts more as a headland, as there is minimal flow through the Palk Strait, the channel between India and Sri Lanka. The flow follows the curvature of the southern coast of Sri Lanka and generates a lee eddy in the form of the Sri Lanka Dome. Using values of $L \sim 200 \mathrm{~km}, U \sim 0.8 \mathrm{~ms}^{-1}$, and $K_{\mathrm{h}} \sim 10^{4} \mathrm{~m}^{2} \mathrm{~s}^{-1}$ yields a Reynolds number $\left(R_{\mathrm{e}}=U L / K_{\mathrm{h}}\right.$; see Sect. 1) of $\sim 20$ which predicts an attached eddy, which is the Sri Lanka Dome (Fig. 1). This is confirmed by the idealised model runs with constant westerly winds which predict a stronger eddy with increasing wind (flow) speeds (Fig. 15). Here, the Reynolds numbers range from 5 (Fig. 15a) to 20 (Fig. 15d), and the model runs indicate an attached eddy in the lee of the island, with its strength increasing with increasing westerly winds.

2. During both the SW and NE monsoons, the model results indicated southward flow along both the eastern and western coasts, converging along the southern coast. In this case, circulation is similar to that of an island with no discernible wake - defined as attached flow (e.g. Alaee et al., 2004). The currents are now weaker, and using values of $L \sim 100 \mathrm{~km}, U \sim 0.1 \mathrm{~ms}^{-1}$, and $K_{\mathrm{h}} \sim 10^{4} \mathrm{~m}^{2} \mathrm{~s}^{-1}$ yields a Reynolds number $R_{\mathrm{e}}=\sim 1$ in agreement with the theoretical predictions.

Flow along the southern coast of Sri Lanka in both monsoons is subject to curvature which can lead to secondary circulation (Alaee et al., 2004). Here, as a result of the curvature-induced centrifugal acceleration, the surface waters move offshore and are replaced by water from the subsurface. In the case of Sri Lanka, although located close to the Equator, scaling reveals that the Coriolis force is important in the dynamics (Rossby number $R_{\mathrm{O}}<1$ ) and that, according to the flow regime proposed by Alaee et al. (2004), flow curvature is negligible in the generation of the secondary circulation when compared to the Coriolis force (regime $\mathrm{B}$, where $R_{\mathrm{O}}<1$ and $R_{\mathrm{e}}>1$; Alaee et al., 2004). To investigate the importance of the Coriolis term further, model simulations were undertaken with the inclusion and exclusion of the Coriolis force during the SW monsoon. The results indicate that when the Coriolis force was omitted, there was no upwelling (colder water) to the west of Sri Lanka, particularly off the southern Indian coast (Fig. 16). The upwelling feature with convergent flow to the southeast of the island is present in both simulations, but is enhanced and pronounced in the model run with the inclusion of the Coriolis force. Hence, although the Coriolis force is important in the dynamics of the region, it does not appear to play a major role in the upwelling along the southern coast of Sri Lanka.

In terms of upwelling patterns, case (1) clearly indicates the presence of higher SCC within the Sri Lanka Dome (Fig. 8), and Vinayachandran and Yamagata (1998) indicated well-developed upward doming isotherms in a climatological cross section of the dome. The main upwelling observed in 

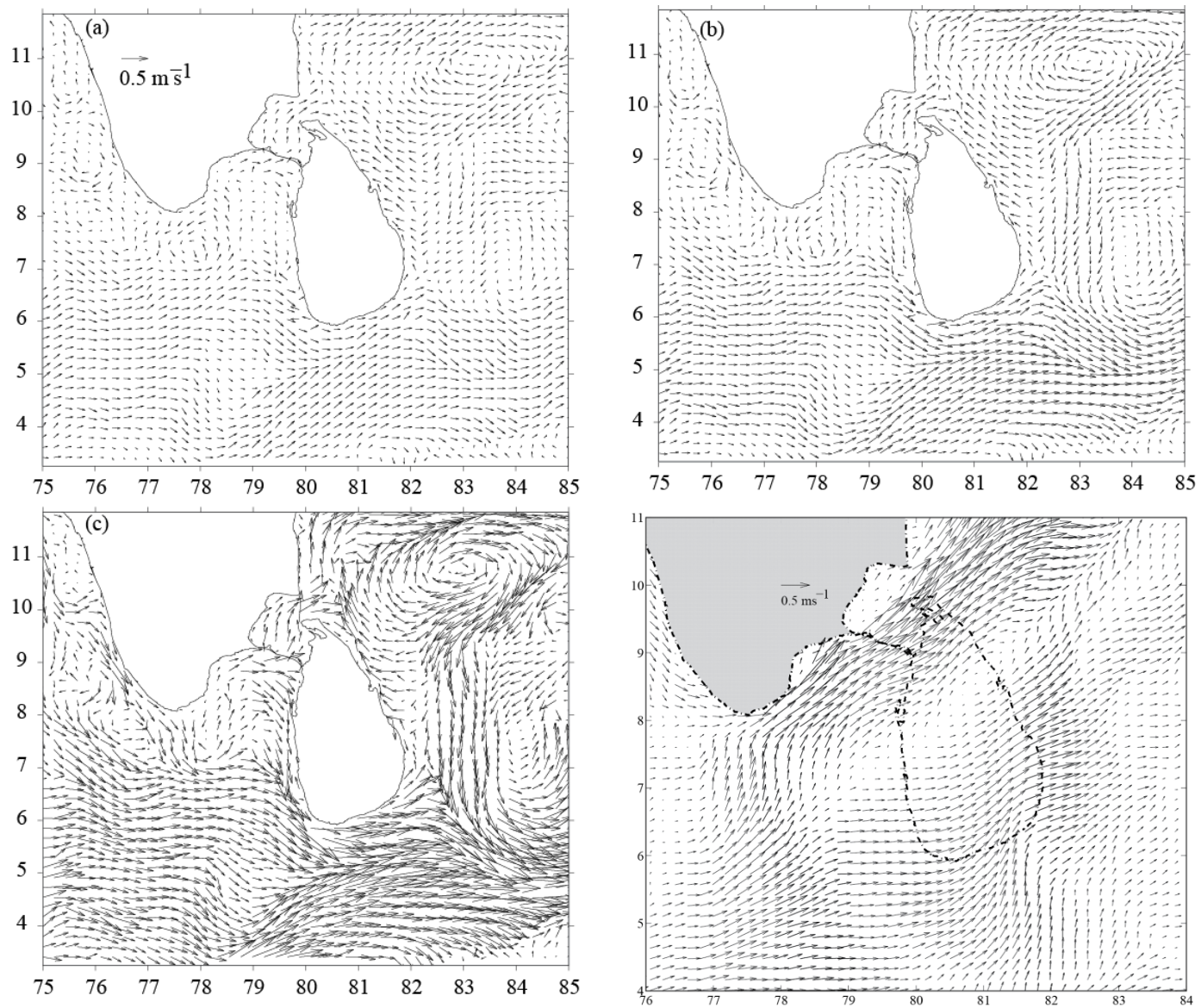

Figure 18. Predicted surface currents under constant westerly winds at (a) $2 \mathrm{~ms}^{-1}$, (b) $4 \mathrm{~ms}^{-1}$, (c) $6 \mathrm{~ms}^{-1}$ and (d) without the Sri Lankan island.

the satellite imagery, both in terms of climatology (Fig. 3) and individual dates (Fig. 8), indicates the dominant upwelling regions along the southern coast of Sri Lanka. Examining the climatological monthly means indicates a wide band of higher SCC offshore of the southern coast which could be attributed to wind-driven coastal upwelling due to Ekman dynamics. However, individual satellite images and numerical model outputs indicate that the mechanism of upwelling is more complicated. Located in the tropics, the region is frequently under cloud cover, and cloud-free satellite imagery is very limited. Examination of the complete 10 -year archived daily images in the ocean colour imagery database (Feldman and McClain, 2013) yielded fewer than 10 cloud-free images for the region. However, these images often indicate similar patterns of upwelling where there is a "tongue" (triangular shape) of high SCC water, with the wider section attached to the coast and tapering offshore (Fig. 3). The location of this tongue varied along the southern coast, and was present during both the SW and NE monsoon periods. Similarly high SCC patterns were reported by Vinayachandran et al. (2004) (Fig. 3). Although the numerical model did not include a biophysical model to simu- late phytoplankton growth (chlorophyll), the predicted SST distribution was remarkably similar to the higher SCC patterns and the associated SST patterns observed by satellites (Fig. 3). The model output indicated that the lower SST patterns were associated with regions of convergence: currents from both the eastern and western coasts converged in the upwelling centre defined by lower SST, and the idealised model runs indicated that the location of the upwelling centre was dependent on the relative wind stress along each coast. During the NE monsoon, the upwelling centre was shifted to the west, whilst during the SW monsoon, the upwelling centre was shifted to the east (Fig. 17). It should also be noted that the southern coast of Sri Lanka has a narrow continental shelf; hence, shelf processes as a primary mechanism for upwelling may be neglected. There are no previous studies which have addressed this type of circulation pattern and upwelling: interaction between convergent flows around an island leading to upwelling. The island of Taiwan has a similar oceanographic setting, with northward currents along both coastlines converging to the north of the island, with upwelling along the northeastern corner (Chang et al., 2010). However, numerical experiments indicate that 


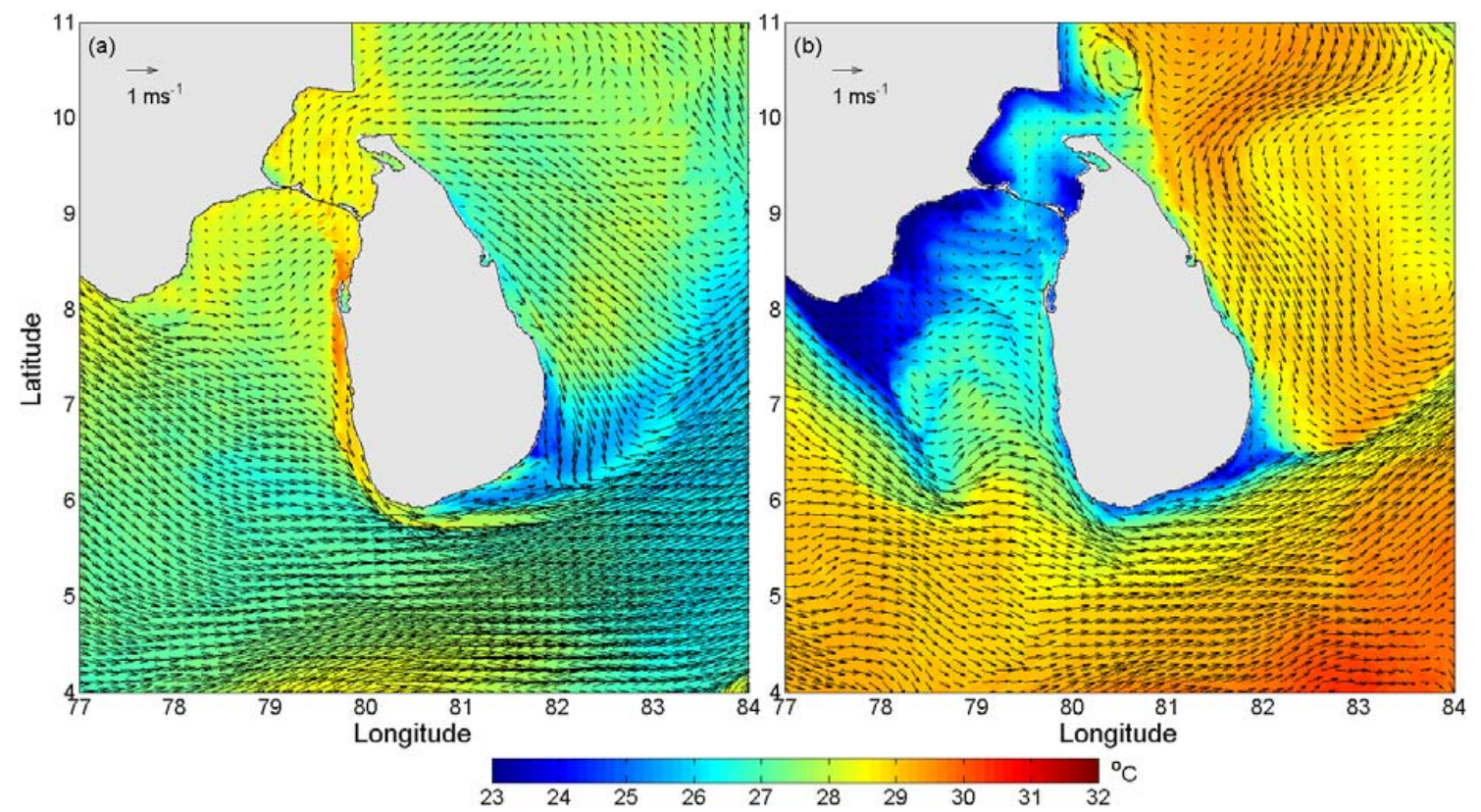

Figure 19. Predicted near-surface current vectors plotted on the surface temperature field on 15 June 2011. (a) Simulation excluding Coriolis forcing, and (b) simulation including Coriolis forcing.

there is recirculation to the north of the island, and the upwelling is due mainly to the Kuroshio current encroaching onto the shelf (Chang et al., 2010). On a smaller scale, Magnell et al. (1990) show enhanced upwelling at Cape Mendocino resulting from converging currents at the tip of the cape. Through continuity, horizontal divergence at the sea surface results in vertical upwelling of water from depth. The numerical model results, confirmed by the high SCC patterns, confirm this process: the currents flowing parallel to the eastern and western coasts converge along the southern coast and are deflected offshore. As the water is flowing offshore, there is divergence of water at the coast, which results in upwelling of colder water from depth. This was confirmed by the numerical model output, which indicated a lower sea surface height at the centre of upwelling.

The observation that blue whales (Balaenoptera musculus) feed off the southern coast of Sri Lanka during the NE monsoon period (de Vos et al., 2014) provided the motivation for this study. The NE winds, under Ekman dynamics, would generate a downwelling system (onshore Ekman flow) along the southern coast of Sri Lanka, resulting in a low primary productive system. The results of this study are able to explain that the upwelling system along the southern coast of Sri Lanka is not driven by Ekman dynamics, but rather by an interaction of the wind-driven circulation around the island. This results in a converging coastal current system that flows offshore, creating a divergence at the coastline, resulting in upwelling which is able to maintain a relatively higher productivity system during both monsoon periods.

\section{Conclusions}

This paper has explored the elements of the dynamics of the surface circulation and coastal upwelling in the waters around Sri Lanka, located in the northern Indian Ocean, a region influenced by seasonally reversing monsoon winds, through satellite imagery and a numerical model. Numerical model predictions compared well with the limited field data and satellite observations. The main conclusions may be summarised as follows:

1. The results confirmed the presence of the eastward flowing Southwest Monsoon Current (SMC) during the SW monsoon and the westward flowing Northeast Monsoon Current (NMC), respectively. The predicted mean transports over the period 2010-2012 for the SMC and NMC were 11.5 and $9.6 \mathrm{~Sv}$, respectively.

2. Sri Lanka Dome, a recirculation feature located to the east of Sri Lanka during the SW monsoon, is the result of the interaction between SMC and the island, resulting in a recirculation eddy. It is possible that the eddy is enhanced through wind stress curl.

3. During both monsoon periods, the flow along the eastern and western coasts was southward, converging along the southern coast. During the SW monsoon, the island deflected the eastward flowing SMC southward, whilst along the eastern coast, the southward flow results from the Sri Lanka Dome recirculation. 
4. The major upwelling region, during both monsoon periods, is located along the southern coast, and results from flow convergence and the associated offshore transport of water. Higher SCC values were observed during the SW monsoon. The location of the flow convergence and hence the upwelling centre was dependent on the relative strengths of wind-driven flow along the eastern and western coasts: during the SW (NE) monsoon, the flow along the western (eastern) coast was stronger, and hence the upwelling centre was shifted to the east (west).

Acknowledgements. A. de Vos was supported by a UWA Scholarship for International Research Fees (SIRF).

Edited by: R. Hood

\section{References}

Alaee, J. M., Ivey, G., and Pattiaratchi, C.: Secondary circulation induced by flow curvature and Coriolis effects around headlands and islands, Ocean Dynam., 54, 27-38, 2004.

Alaee, J. M., Pattiaratchi, C. B., and Ivey, G. N.: Numerical simulation of the summer wake of Rottenest Island, Western Australia, Dynam. Atmos. Oc., 43, 171-198, 2007.

Barkley, R. A.: Johnston Atoll's wake, J. Mar. Res., 30, 210-216, 1972.

Barton, E. D., Basterretxea, G., Flament, P., Mitchelson-Jacob, E. G., Jones, B., Arístegui, J., and Herrera, L.: region of Gran Canaria, J. Geophys. Res., 105, 173-117, 2000

Bleck, R.: An oceanic general circulation model framed in hybrid isopycnic-cartesian coordinates, Oc. Modell., 4, 55-88, 2002.

Bowman, M. J., Dietrich, D. E., and Lin, C. A.: Observations and modelling of mesoscale ocean circulation near a small island, in: Small Islands: Marine Science and Sustainable Development, Coastal and Estuarine Studies, edited by: Maul, G., American Geophysical Union, Washington DC, 18-35, 1996.

Bucciarelli, E., Blain, S. P., and Tréguer, P.: Iron and manganese in the wake of the Kerguelen Islands (Southern Ocean), Mar. Chem., 73, 21-36, 2001.

Caldeira, R. M. A., Groom, S., Miller, P., Pilgrim, D., and Nezlin, N. P.: Sea-surface signatures of the island mass effect phenomena around Madeira Island, Northeast Atlantic, Remote Sens. Environ., 80, 336-360, 2002.

Chang, Y.-L., Oey, L.-Y., Wu, C.-R., and Lu, H.-F.: Why are there upwellings on the northern shelf of Taiwan under northeasterly winds?, J. Phys. Oceanogr., 40, 1405-1417, 2010.

Cowen, R. K. and Castro, L. R.: Relation of coral reef fish larval distributions to island scale circulation around Barbados, West Indies, Bull. Mar. Sci., 54, 228-244, 1994.

de Vos, A., Pattiaratchi, C. B., and Harcourt, R. G.: Inter-annual variability in blue whale distribution off southern Sri Lanka between 2011 and 2012, J. Mar. Sci. Engin., 2, 534-550, 2014.

Di Lorenzo, E., Moore, A. M., Arango, H. G., Cornuelle, B. D., Miller, A. J., Powell, B., Chua, B. S., and Bennett, A. F.: Weak and strong constraint data assimilation in the inverse Regional
Ocean Modeling System (ROMS): Development and application for a baroclinic coastal upwelling system, Ocean Model. Online, 16, 160-187, 2007.

Dong, C. and McWilliams, J. C.: A numberical study of island wakes in the Southern California Bight, Cont. Shelf Res., 27, 1233-1248, 2007.

Dong, C., Idica, E. Y., and McWilliams, J. C.: Circulation and multiple-scale variabiltiy in the Southern California Bight, Prog. Oceanogr., 82, 168-190, 2009.

Doty, M. S. and Oguri, M.: The island mass effect, J. Conserv., 22, 33-37, 1956.

Durand, F., Shankar, D., Birol, F., and Shenoi S. S. C.: Spatiotemporal structure of the East India Coastal Current from satellite altimetry, J. Geophys. Res. (oceans), 114, C02013, doi:10.1029/2008JC004807, 2009.

Hafner, J. and Xie, S.-P.: Far-field simulation of the Hawaiian wake: Sea surface temperature and orographic effects, J. Atmos. Sci., 60, 3021-3032, 2003.

Haidvogel, D. B., Arango, H., Budgell, W. P., Cornuelle, B. D., Curchitser, E., Di Lorenzo, E., Fennel, K., Geyer, W. R., Hermann, A. J., Lanerolle, L., Levin, J., McWilliams, J. C., Miller, A. J., Moore, A. M., Powell, T. M., Shchepetkin, A. F., Sherwood, C. R., Signell, R. P., Warner, J. C., and Wilkin, J.: Ocean forecasting in terrain-following coordinates: Formulation and skill assessment of the Regional Ocean Modeling System, J. Computat. Phys., 227, 3595-3624, 2008.

Heywood, K. J., Barton, E. D., and Simpson, J. H.: The effects of flow disturbance by an oceanic island, J. Mar. Res., 48, 55-73, 1990.

Jensen, T. G.: Arabian Sea and Bay of Bengal exchange of salt and tracers in an ocean model, Geophys. Res. Lett., 28, 3967-3970, 2001.

Kabanova, J. G.: Primary production of the northern part of the Indian Ocean, Oceanology, 8, 214-225, 1968.

Legeckis, R.: Satellite observations of a western boundary current in the Bay of Bengal, J. Geophys. Res. (Oceans), 92, 12974-12978, 1987.

Levitus, S., Burgett, R., and Boyer, T. P.: World ocean atlas 1994, NOAA Atlas NESDIS 3, US Government Printing Office, Washington, DC, 1994

Luis, A. J. and Kawamura, H.: Wintertime wind forcing and sea surface cooling near the south India tip observed using NSCAT and AVHRR, Remote Sens. Environ., 73, 55-64, 2000.

Magnell, B. A., Bray, M. A., Winant, C. D., Greengrove, C. L., Largier, J. L., Borchardt, F., Bernstein, R. L., B., and Dorman, C. E.: Convergent shelf flow at Cape Mendocino, Oceanography, 3, 4-11, 1990.

Marchesiello, P., McWilliams, J. C., and Shchepetkin, A.: Open boundary conditions for long-term integration of regional oceanic models, Ocean Model. Online, 3, 1-20, 2001.

Marchesiello, P., McWilliams, J. C., and Shchepetkin, A.: Equilibrium structure and dynamics of the California current system, J. Phys. Oceanogr., 33, 753-783, 2003.

McCreary Jr., J. P., Murtugudde, R., Vialard, J., Vinayachandran, P. N., Wiggert, J. D., Hood, R. R., Shankar, D., and Shetye, S.: Biophysical processes in the Indian Ocean, Geophys. Monogr. Ser., 185, 9-32, 2009.

Michisaki, R. P., Chavez, F. P., Friederich, G. E., and Kelley, M.: Evolution of chemical and biological properties in the Arabian 
Sea and Indian Ocean during 1995 from automated surface mapping, American Geophysical Union Ocean Sciences meeting, San Diego, 1996.

Palacios, D. M.: Factors influencing the island-mass effect of the Galápagos Archipelago, Geophys. Res. Lett., 29, 2134, doi:10.1029/2002g1016232, 2002.

Pattiaratchi, C., James, A., and Collins, M.: Island wakes and headland eddies: A comparison between remotely sensed data and laboratory experiments, J. Geophys. Res. (Oceans), 92, 783-794, 1987.

Pawlowicz, R., Beardsley, B., and Lentz, S.: Classical tidal harmonic analysis including error estimates in MATLAB using T_TIDE, Comput. Geosci., 28, 929-937, 2002.

Saetersdal, G., Bianchi, G., Stomme, T., and Venema, S. C.: The Dr. Fridtjof Nansen Programme 1975-1993: Investigations of fishery resources in developing countries. History of the programme and review of results, Food and Agriculture Organisation of the United Nations, Rome, 434 pp., 1999.

Sahini, A.: The structure, sedimentation and evolution of Indian continental margins, in: The ocean basins and margins: The Indian Ocean, edited by: Nairn, E. M. and Stehli, F. G., Plenum Press, New York, 353-398, 1982.

Schott, F., Reppin, J., Fischer, J., and Quadfasel, D.: Currents and transports of the monsoon current south of Sri Lanka, J. Geophys. Res.-Oceans, 99, 25127-25141, 1994.

Schott, F. A. and McCreary, Jr., J. P.: The monsoon circulation of the Indian Ocean, Prog. Oceanogr., 51, 1-123, 2001.

Shankar, D. and Shetye, S. R.: On the dynamics of the Lakshadweep high and low in the southeastern Arabian Sea, J. Geophys. Res.Oceans, 102, 12551-12562, 1997.

Shankar, D., Vinayachandran, P. N., and Unnikrishnan, A. S.: The monsoon currents in the north Indian Ocean, Prog. Oceanogr., 52, 63-120, 2002.

Shchepetkin, A. F. and McWilliams, J. C.: The regional oceanic modeling system (ROMS): a split-explicit, free-surface, topography-following-coordinate oceanic model, Ocean Model. Online, 9, 347-404, 2005.

Shepard, E. P.: Submarine geology, Harper and Row Publishers, New York, 1963.

Song, Y. and Haidvogel, D.: A semi-implicit ocean circulation model using a generalized topography-following coordinate system, J. Computat. Phys., 115, 228-244, 1994.

Sreenivas, P., Gnanaseelan, C., and Prasad, K. V. S. R.: Influence of El Niño and Indian Ocean Dipole on sea level variability in the Bay of Bengal, Glob. Planet. Change, 80/81, 215-225, 2012.
Swan, B.: An Introduction to the Coastal Geomorphology of Sri Lanka, National Museums of Sri Lanka, Colombo, 1983.

Tomczak, M.: Island wakes in deep and shallow water, J. Geophys. Res., 93, 5153-5154, 1988.

Tomczak, M. and Godfrey, J. S.: Regional oceanography: An introduction, 2 Edn., Pergamon, 2003.

Varkey, M. J., Murty, V. S. N., and Suryanarayana, A.: Physical oceanography of the Bay of Bengal and Andaman Sea, in: Oceanogr. Mar. Biol. Annu. Rev., edited by: Ansell, A. D., Gibson, R. N., and Barnes, M., CRC Press, 1-70, 1996.

Vinayachandran, P. N. and Yamagata, T.: Monsoon response of the sea around Sri Lanka: Generation of thermal domes and anticyclonic vortices, J. Phys. Oceanogr., 28, 1946-1960, 1998.

Vinayachandran, P. N., Masumoto, Y., Mikawa, T., and Yamagata, T.: Intrusion of the southwest monsoon current into the Bay of Bengal, J. Geophys. Res.-Oceans, 104, 11077-11085, 1999.

Vinayachandran, P. N., Chauhan, P., Mohan, M., and Nayak, S.: Biological response of the sea around Sri Lanka to summer monsoon, Geophys. Res. Lett., 31, L01302, doi:10.1029/2003GL018533, 2004.

Wijeratne, E. M. S.: Tidal characteristics and modelling of tidal wave propagation in shallow lagoons of Sri Lanka, Ph.D., Gothenburg University, Gothenburg, 2003.

Wijeratne, E. M. S., Woodworth, P. L., and Stepanov, V. N.: The seasonal cycle of sea level in Sri Lanka and southern India, West Indian Ocean J. Mar. Sci., 7, 29-43, 2008.

Wijeyananda, N. P.: Maritime zones, in: Arjuna's atlas of Sri Lanka, edited by: Somasekaram, T., Perera, M., de Silva, M. B. G., and Godellawatta, H., Arjuna Consulting Company Limited, Colombo, 5-7, 1997.

Wolanski, E., Imberger, J., and Heron, M. L.: Island wakes in shallow coastal waters, J. Geophys. Res., 89, 553-569, 1984.

Wyrtiki, K.: Physical oceanography of the Indian Ocean, in: The Biology of the Indian Ocean, edited by: Zeitzschel, B. and Gerlach, S. A., Springer-Verlag, Heidelberg, 1973.

Xu, J., Lowe, R. J., Ivey, G. N., Pattiaratchi, C. B., Jones, N. L., and Brinkman, R.: Dynamics of the summer shelf circulation and transient upwelling off Ningaloo Reef, Western Australia, J. Geophys. Res.-Oceans, 118, 1099-1125, 2013.

Yapa, K. K. A. S.: Upwelling phenomena in the southern coastal waters of Sri Lanka during southwest monsoon period as seen from MODIS, Sri Lanka J. Phys., 10, 7-15, 2009. 